\title{
Genesis of the Weizigou Au Deposit, Heilongjiang Province, NE China: Constraints from LA-ICP-MS Trace Element Analysis of Magnetite, Pyrite and Pyrrhotite, Pyrite Re-Os Dating and $\mathrm{S}-\mathrm{Pb}$ Isotopes
}

\author{
Yu Gao ${ }^{1}$, Yujie Hao ${ }^{1,2, *}$ and Siyu Lu ${ }^{1}$ \\ 1 College of Earth Sciences, Jilin University, Changchun 130061, China; yug20@mails.jlu.edu.cn (Y.G.); \\ lusy18@mails.jlu.edu.cn (S.L.) \\ 2 Key Laboratory of Mineral Resources Evaluation of Northeast Asia, Ministry of Natural Resources, \\ Changchun 130026, China \\ * Correspondence: haoyujie@jlu.edu.cn
}

check for

updates

Citation: Gao, Y.; Hao, Y.; Lu, S. Genesis of the Weizigou Au Deposit, Heilongjiang Province, NE China: Constraints from LA-ICP-MS Trace Element Analysis of Magnetite, Pyrite and Pyrrhotite, Pyrite Re-Os Dating and $\mathrm{S}-\mathrm{Pb}$ Isotopes. Minerals 2021, 11, 1380. https://doi.org/10.3390/ $\min 11121380$

Academic Editors: Dan Asael, Tamer Abu-Alam and Basem Zoheir

Received: 21 October 2021

Accepted: 4 December 2021

Published: 7 December 2021

Publisher's Note: MDPI stays neutral with regard to jurisdictional claims in published maps and institutional affiliations.

Copyright: (C) 2021 by the authors. Licensee MDPI, Basel, Switzerland. This article is an open access article distributed under the terms and conditions of the Creative Commons Attribution (CC BY) license (https:/ / creativecommons.org/licenses/by/ $4.0 /)$.

\begin{abstract}
The Weizigou Au deposit in Heilongjiang Province, NE China, located in the southern Jiamusi Massif, shows similarities to IOCG deposits. To determine the mineralization age, sources of ore-forming materials and genetic type, pyrite Re-Os dating, $\mathrm{S}-\mathrm{Pb}$ isotopic analysis, in situ sulfur analysis and LA-ICP-MS analysis of trace elements in magnetite, pyrite and pyrrhotite were conducted. Four pyrite samples yielded a Re-Os isochron age of $197 \pm 11 \mathrm{Ma}$, implying the occurrence a metallogenic event in the Early Jurassic. The $\delta^{34} \mathrm{~S}$ values of sulfides display a relatively narrow range from $4.70 \%$ to $12.83 \%$ o (mainly $9.90 \%$ o to $12.83 \%$ ), which may be accounted for the extensively exposed granitic gneiss and meta-gabbro, with $\delta^{34} \mathrm{~S}$ values of $7.44 \%$ o to $8.44 \%$ and $4.37 \%$ to $10.54 \%$, respectively. Sulfide lead isotopic compositions have ${ }^{206} \mathrm{~Pb} /{ }^{204} \mathrm{~Pb}=18.605-20.136$, ${ }^{207} \mathrm{~Pb} /{ }^{204} \mathrm{~Pb}=15.637-15.710$ and ${ }^{208} \mathrm{~Pb} /{ }^{204} \mathrm{~Pb}=38.534-39.129$, indicating that the lead was derived from a mixed source. Magnetite has the characteristics of a lower Ti content and higher $\mathrm{Zn}$ content, indicating that it should be of hydrothermal origin, which may be related to IOCG-type mineralization. Pyrite and pyrrhotite have a Co/Ni ratio greater than 1 and a lower As content, indicating that they are of magmatic hydrothermal origin. Integrating the above analysis results, we inferred that the Weizigou Au deposit experienced the IOCG-type mineralization in the Middle-Late Permian, associated with magmatic-hydrothermal mineralization in the Early Jurassic.
\end{abstract}

Keywords: Weizigou Au deposit; LA-ICP-MS; pyrite Re-Os dating; S-Pb isotope; IOCG deposit

\section{Introduction}

Iron oxide-copper-gold (IOCG) deposits are one of the main sources of copper $(\mathrm{Cu})$ and gold $(\mathrm{Au})$ in the world [1-3]. Since one of the world's greatest IOCG deposits was discovered at the Olympic Dam at the Gawler Craton in South Australia in 1975 [4], the IOCG deposit category has attracted considerable attention [5-14]. Our understanding of IOCG deposits has gradually deepened over the past two decades [9,12]. Generally, these deposits contain massive and disseminated iron oxides (magnetite and/or hematite). The style of mineralization and geometry of the mineralized bodies vary from veins and stockworks to breccia pipes or discordant bodies [5]. Commonly, IOCG deposits lack a demonstrated intimate relationship with particular intrusive phases [12].

In recent years, the chemical composition of magnetite, pyrite, pyrrhotite and other sulfides has been the focus of scholarship in related fields. Decades of research progress have made the geochemical composition of the above minerals a powerful tool for constraining the genesis of deposits, the origin of trace materials, and tracing ore-forming fluids. [15-20]. At first, electron probe micro-analyzer (EMPA) was used to determine the contents of several trace elements in minerals, such as $\mathrm{Mg}, \mathrm{Ca}, \mathrm{Ti}, \mathrm{V}$ and $\mathrm{Cr}$. However, 
this method is not accurate enough for measuring the data of certain trace elements, and the results often deviate from the actual situation. With the development of technology, in situ laser ablation inductively coupled plasma mass spectrometry (LA-ICP-MS) has become an effective and accurate method for the analysis of trace elements in oxides and sulfides [18,21-25].

The Weizigou Au deposit was discovered by the First Detachment of the Gold Headquarters of the China Armed Police Force in 2002. Previous studies have determined the metallogenic conditions, mineralization characteristics, source of metallogenic materials and ideal prospecting direction, as well as conducting mineral prospecting through exploration geophysics and geochemistry in the orefield. It was considered that the formation of the Weizigou gold deposit is closely related to the early Paleozoic granitic gneiss and is a metamorphic-hydrothermal gold deposit directly related to the regional advanced metamorphism [26-29]. However, despite its small size, based on our field observations and analyses, we have determined that it shares many similarities with the IOCG deposit, which is rare in northeastern China. The lack of systematic studies of single minerals has limited our understanding of the genesis and mineralization processes of the deposit. Therefore, a detailed study of the Weizigou gold deposit is necessary in order to reveal whether it is an IOCG deposit.

Therefore, in this study, we conduct an LA-ICP-MS analysis of trace elements in magnetite, pyrite and pyrrhotite; pyrite Re-Os dating; an $\mathrm{S}-\mathrm{Pb}$ isotopic and in situ analysis of sulfur isotopic data, integrating other obtained results, to constrain the sources of oreforming materials, determine the ore genesis and, ultimately, reveal the details of the ore-forming process ultimately.

\section{Geological Background}

The geotectonic location of the Weizigou mining area is located in the south-central part of the Jiamusi block, east of the Mudanjiang abyssal fault and north of the DunhuaMishan fault zone (Figure 1a). In addition to Quaternary strata, geological units exposed in the area include the Mashan complex (former "Mashan Group"), the Heilongjiang complex (former "Heilongjiang Group"), Paleozoic-Mesozoic granitic rocks and sedimentary rock (Heilongjiang Bureau of Geology and Mineral Resources [30-34] (Figure 1b).

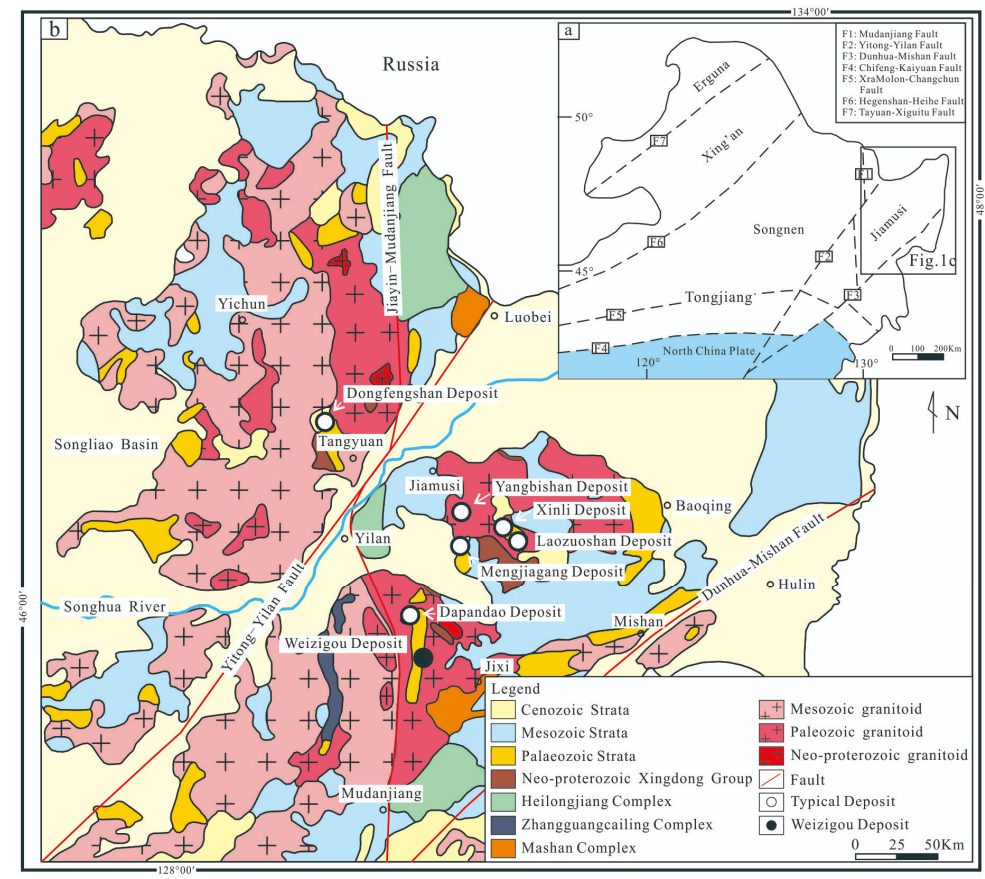

Figure 1. (a) Tectonic location map of Northeast China (modified after Wu et al. [35]); (b) regional geological map of Jiamusi Area (modified after Wang et al. [29]). 
Among these, the Mashan complex is considered to be the metamorphic basement of the Jiamusi massif. It is composed of a set of khondalite series containing graphite and phosphorus that is aluminum rich and intercalated with marble, calcium silicate rocks and quartz schist. This series has undergone amphibolite facies to granulite facies metamorphism and is mainly distributed in Jixi, Luobei and other areas [34,36-38]. The Heilongjiang complex is mainly distributed in the north and south of the region and shows an irregular distribution. Generally, the complex is a set of argillaceous schist, metamorphic basic rock, ultrabasic rock, metamorphic siliceous rock and marble formed by the metamorphism of blue schist-green schist facies affected by intense deformation in the later period. This complex has been considered as ophiolite structural melanges formed in during the collage of the Jiamusi block and the Songliao block. [32,39-41]. The sedimentary caprocks of the Paleo-Mesozoic are mainly distributed across the eastern margin of the region, including two structural layers from the bottom to the top. The bottom part is the Lower Devonian-Lower Carboniferous marine and marine-terrestrial clastic rocks, which are unconformized in the Early Paleozoic granite, while the upper part is developed with Upper Carboniferous-Lower Cretaceous continental clastic rocks and volcanic rocks. [30,33,34,42].

The faults in this region include the Mudanjiang fault, the Yitong-Yilan fault and the Dunhua-Mishan fault (Figure 1b). The Mudanjiang fault is divided into two parts: Tangyuan-Jiayin in the north and Mudanjiang-Yilan in the south. It extends to Russia through Heilongjiang Province, with a total length of about $500 \mathrm{~km}$ and spreads along the Mudanjiang valley in the SN direction. The Yitong-Yilan fault is one of the most important branches of the Tancheng-Lujiang super-lithospheric fault zone that extends northward, running from the northeast to Luobei via Shulan. The Dunhua-Mishan fault is also the northern extension of the Tancheng-Lujiang fault zone. It enters Jilin via Yingkou-Fushun, Liaoning and extends northeast [34,43].

Magma activity is strong in this area. Early Paleozoic granitic rocks are the product of Pan-African period (541-484 Ma) magmatism, and together with the Mashan complex form the metamorphic crystalline basement of the Jiamusi block. The Late CarboniferousPermian (305-250 Ma) and Late Triassic-Cretaceous (223-88 Ma) magmatic rocks are considered to be the result of the different evolution stages of the block being affected by the Paleo-Asian Ocean and Paleo-Pacific tectonic domains [34,35,44-50].

\section{Deposit Geology}

The Weizigou deposit, located $30 \mathrm{~km}$ northwest of Jixi City, Heilongjiang Province, is a small gold deposit. Geological investigation and preliminary studies have shown that the strata exposed in the mining area are mainly of the Lower Proterozoic Jiantang Formation, the Liumao Formation and Quaternary strata (Figure 2a). Influenced by intense metamorphism including regional metamorphism and migmatization, substantial regional metamorphic rocks composed of crystalline schist, gneiss and marble were distributed in the south, while migmatite composed of banded migmatite, porphyritic migmatite and migmatitic granite was distributed in the central-north regions [27,29]. All orebodies are closely associated with veined meta-gabbro (Figure $2 b$ ), which is controlled by structural fractures.

The profile of ore body exposed to the surface can be seen in the mining area (Figure $3 a, b$ ). From the profile, it is clear that the veined meta-gabbro intrudes into the granitic gneiss (Figure 3c), the xenolith of granitic gneiss can be seen in the meta-gabbro (Figure 3d) and the ore body in close contact with the metagabbro (Figure 3e).

The granitic gneiss has a granoblastic metamorphic texture with a massive and banded structure (Figure 4a). The main minerals present are feldspar, quartz and small amounts of biotite, monazite, muscovite and garnet, implying a protolith of argillite (Figure 4e). Part of the biotite has been changed into chlorite (Figure 4e), which may have been caused by the superimposition of late metamorphism. The meta-gabbro has a granoblastic metamorphic texture and massive structure (Figure $4 \mathrm{~b}, \mathrm{c}$ ). The main minerals are plagioclase, amphibole 
and biotite, with a small amount of sphene (Figure 4f). Associated minerals include fluorite and titanite.
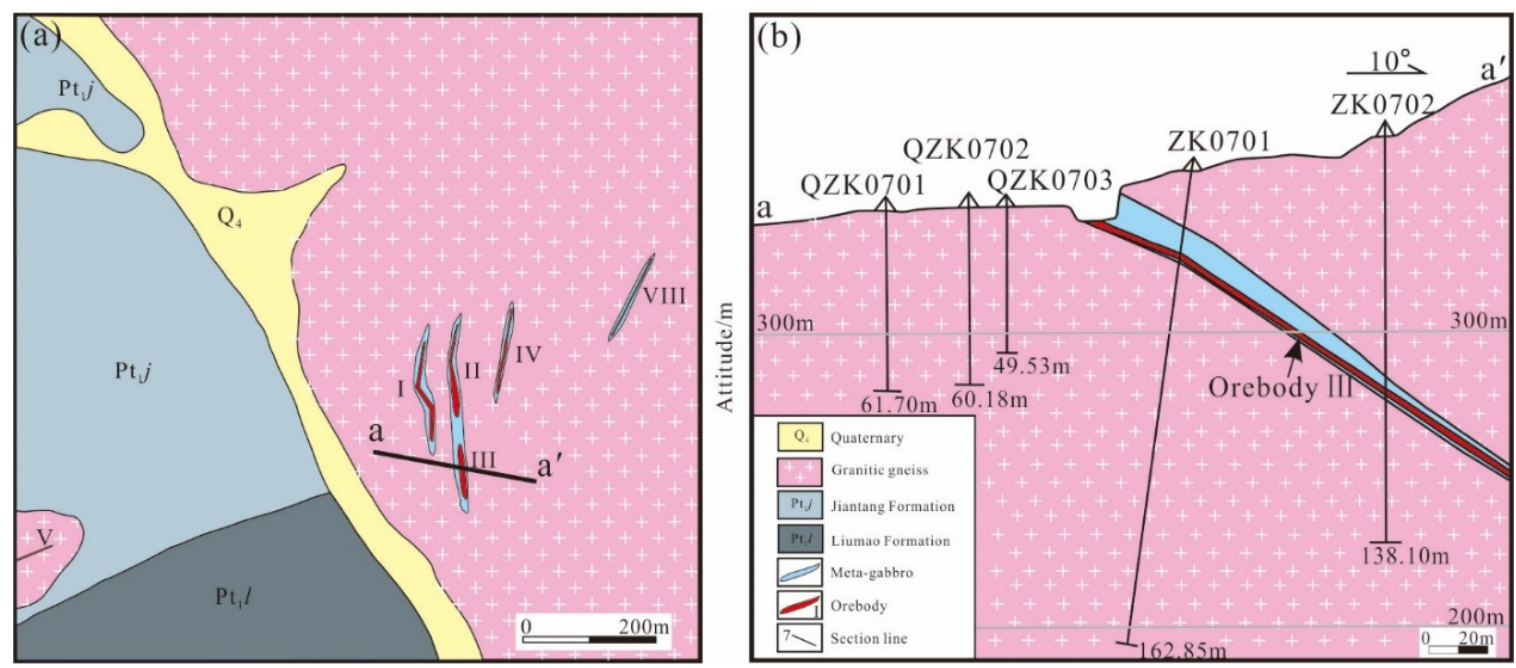

Figure 2. (a) Geological map; (b) exploration line of the Weizigou deposit.
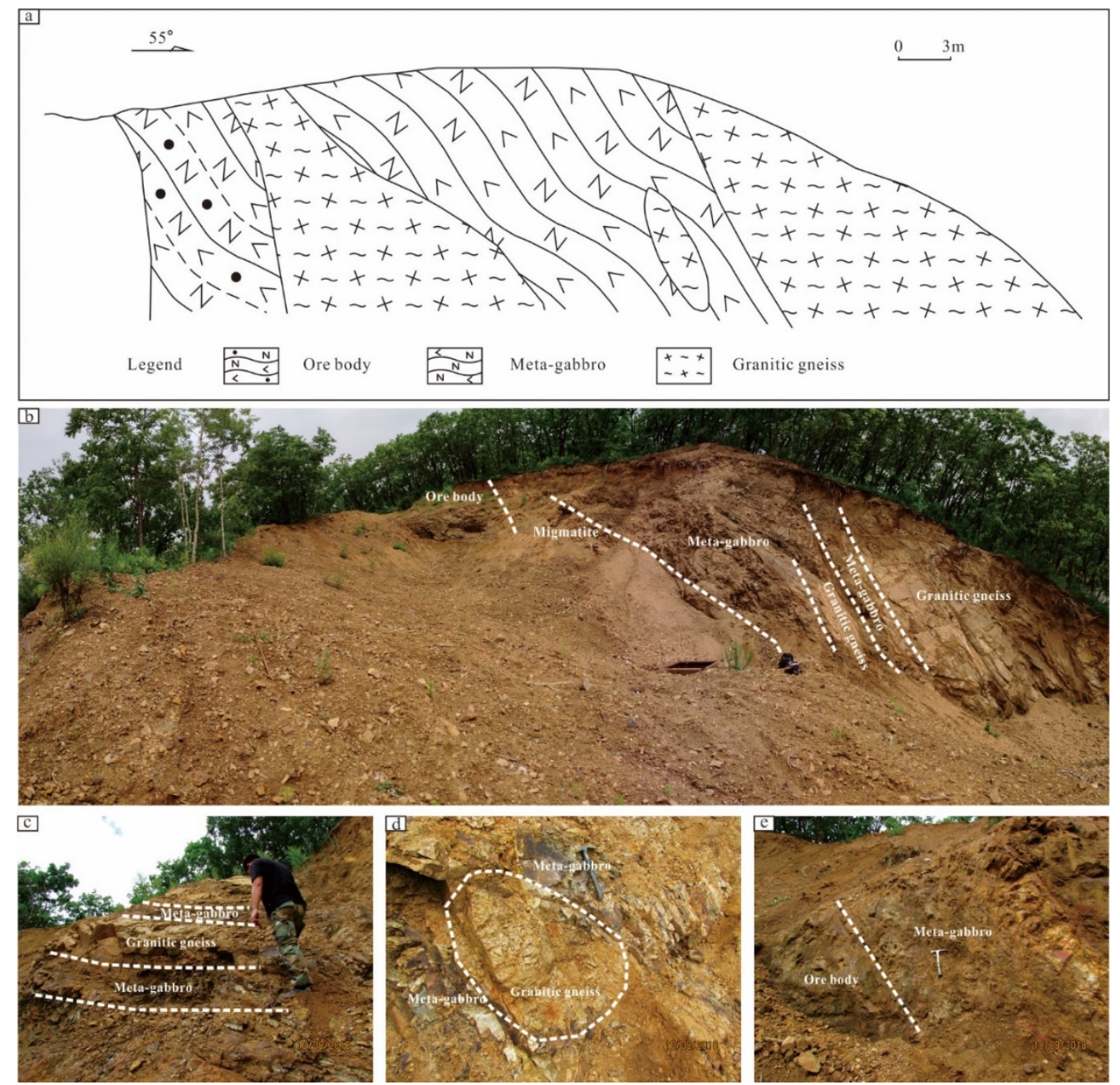

Figure 3. Ore body characteristics: (a) sketch of an outcrop of the ore body; (b) outcrop profile of the ore body; (c) meta-gabbro intrusion into granitic gneiss; (d) granitic gneiss xenoliths in the meta-gabbro; (e) boundary between meta-gabbro and the ore body. 

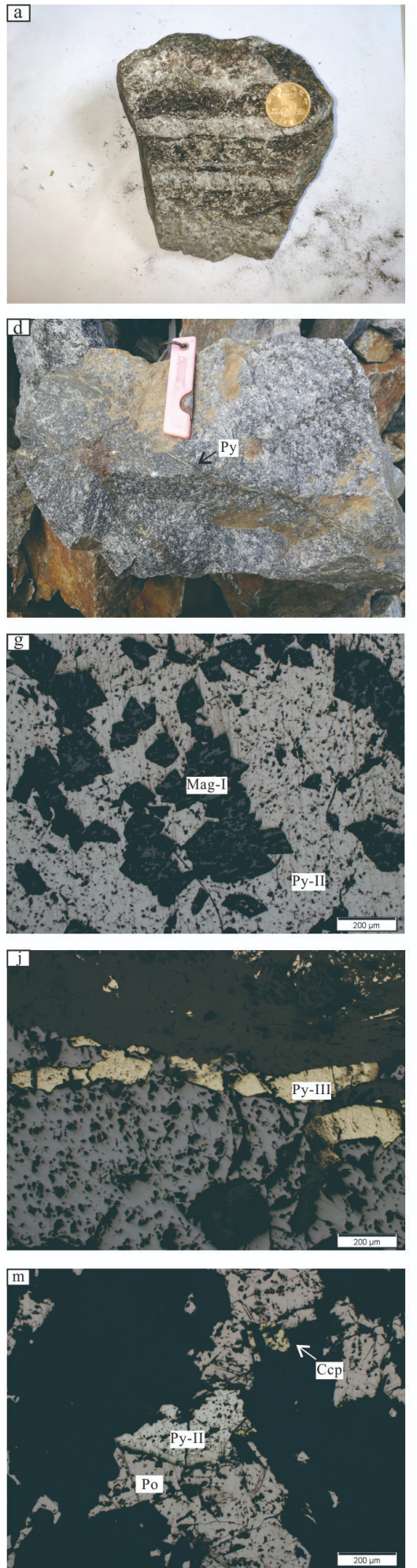
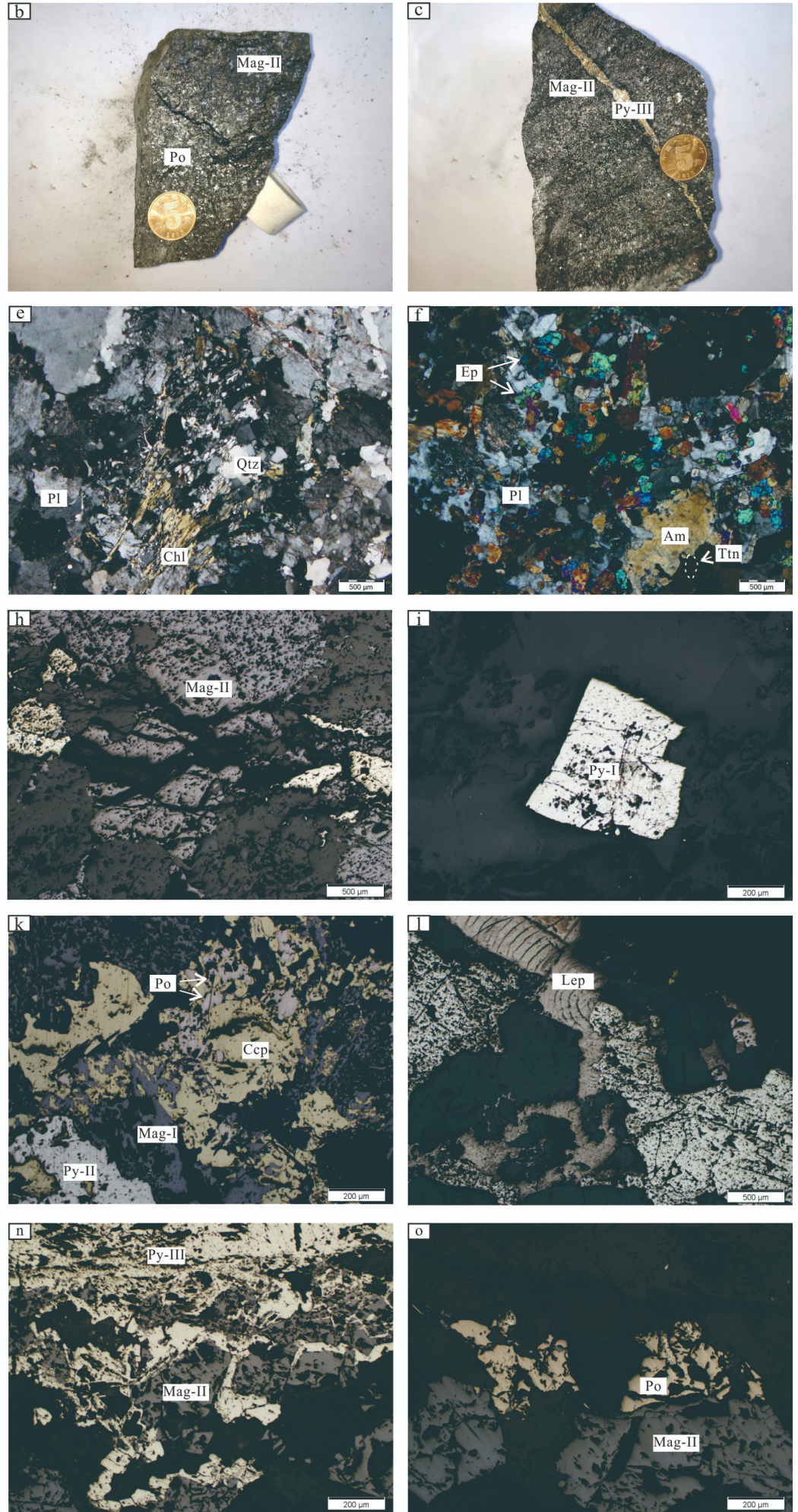

Figure 4. Photos/photomicrographs of migmatitic granite and amphibolite at the Weizigou deposit: (a) hand specimen of granitic gneiss; (b) hand specimen of ore-bearing meta-gabbro; (c) vein-like pyrite in meta-gabbro; (d) pyrite veinlets in granitic gneiss; (e) retrogressive metamorphism of biotite into chlorite in the granitic gneiss; (f) sericite and epidote alteration in the meta-gabbro; (g) euhedral magnetite (Mag-I); (h) disseminated magnetite (Mag-II); (i) euhedral pyrite (Py-I); (j) vein pyrite (Mag-III) is distributed along the fracture or edge of magnetite (Mag-II); (k) chalcopyrite, pyrite (Py-II) and pyrrhotite; (1) lepidocrocite; (m) hypidiomorphic pyrite (Py-II) and pyrrhotite; (n) disseminated magnetite (Mag-II) replaced by pyrite (Py-III); (o) disseminated magnetite (Mag-II) and pyrrhotite. Am-amphibole; Ccp—chalcopyrite; Chl—chlorite; Ep-epidote; Mag—magnetite; Pl—Plagioclase; Po—pyrrhotite; Py—pyrite; Qtz-Quartz; Ttn—titanite. 
Four gold ore bodies (I-IV) and four gold mineralized bodies (V-VII) have been discovered in the mining area. The largest ore body (No. II) is $115 \mathrm{~m}$ long, $50 \mathrm{~m}$ deep, and $0.98-4.11 \mathrm{~m}$ thick. It dips at $43^{\circ}$ to $45^{\circ}$ and has an average grade of $9.17 \times 10^{-6} \mathrm{~g} / \mathrm{t}$. The reserves of ore body II account for $40 \%$ of the Weizigou deposit. The second largest orebody (I) is $100 \mathrm{~m}$ long, $3.56 \mathrm{~m}$ thick on average, and dips at $55^{\circ}$ to $75^{\circ}$, with an average grade of $13.76 \times 10^{-6} \mathrm{~g} / \mathrm{t}$. Orebody III is $55 \mathrm{~m}$ long, $50 \mathrm{~m}$ deep, dips at $44^{\circ}$, and contains $287 \mathrm{~kg}$ of gold with an average grade of $4.69 \times 10^{-6}$. Orebody IV is $90 \mathrm{~m}$ long, dips at $40^{\circ}$, and, also, contains $287 \mathrm{~kg}$ gold with an average grade of $7.22 \times 10^{-6}$. Metallic minerals include magnetite, pyrite, pyrrhotite and chalcopyrite. Gold is mainly native gold and a small amount is electrum, which mainly occurs in magnetite in the form of intergranular gold [27]. Fe mineralization has a close temporal and spatial relationship with meta-gabbro, which is not developed in the granitic gneiss, but there are also quartzpyrite veins that cut through the granitic gneiss (Figure 4d). According to the mineral structure and the metasomatic relationship between minerals, two types of magnetite have been identified. The euhedral magnetite (Mag-I) was replaced by gangue minerals (Figure $4 \mathrm{~g}$ ) and the hypidiomorphic-xenomorphic granular magnetite (Mag-II) occurs in the form of dense fine-grained aggregates (Figure 4h). Pyrite occurs in euhedral (Py-I, Figure 4i), hypidiomorphic-xenomorphic granular (Py-II, Figure 4k) and coarse-veined forms (Py-III, Figure 4j,n). They are metasomatized by xenomorphic chalcopyrite, pyrrhotite (Figure $4 \mathrm{k}, \mathrm{m}, \mathrm{o}$ ) and lepidocrocite (Figure 4l). Gangue minerals include quartz and calcite.

The wall rock alteration is mainly made up of potassium-sodium alteration (potassium feldspar-sericite—sodium zoisite), chlorite and epidote. Among them, the chlorite and potassium alteration developed in the proximal position of mineralization. In the meta-gabbro around the ore body, plagioclase develops strong sericitization and epidote alterations, while amphibole develops chlorite and biotization alterations. The sodium alteration and argillic alteration are developed in the remote position of mineralization.

According to the crosscutting relations and mineral paragenesis, the mineralization can be divided into magmatic, metamorphic hydrothermal and magmatic hydrothermal stages. Minor, fine-grained, euhedral pyrite (Py-I) and magnetite (Mag-I) occur in the magmatic stage. A large amount of hypidiomorphic-xenomorphic magnetite (Mag-II) occur in the metamorphic hydrothermal stage, representing the major period of Au mineralization. The magmatic hydrothermal stage can be classified into two substages: (i) pyrite (Py-II)pyrrhotite-chalcopyrite and (ii) pyrite (Py-III)-lepidocrocite-quartz-calcite. Substage I is mainly characterized by hypidiomorphic-xenomorphic pyrite metasomatized by pyrrhotite and chalcopyrite. Substage II generates abundant veinlet pyrite, lepidocrocite and quartzcalcite veins.

\section{Samples and Analytical Methods}

Eight pyrite (Py-II) samples (Nos. WZG7-4-10, 10-2), which cut the magnetite (Mag-II), were collected from the No. 1 and No. 2 orebodies and the open pit for Re-Os isotopic analysis.

Three ore samples (Nos. WZG-12-2, 1-2, 6-5) were collected and used for the in situ LA-ICP-MS testing of magnetite, pyrite and pyrrhotite. Among them, sample WZG-12-2 is magnetite (Mag-II-A) ore containing veined pyrite (Py-III); WZG-1-2 is magnetite (MagII-B) ore containing pyrite (Py-II) near the center of the No. 3 ore body and WZG-6-5 is sulfide ore containing pyrite (Py-II) and pyrrhotite.

Sulfides (Py-II, Py-III, chalcopyrite and pyrrhotite) were collected from the No. 1 and No. 2 orebodies and the open pits for $\mathrm{S}-\mathrm{Pb}$ isotopic analysis and in situ sulfur isotopic analysis. Granitic gneiss and meta-gabbro were collected from Levels 341 and 302, and the open pits for whole-rock sulfur isotopic analysis.

\subsection{Pyrite Re-Os Dating}

Eight pyrite samples (Nos. WZG7-4-10, 10-2) were crushed for Re-Os isotopic analysis. The decomposition and purification of the pyrite, and separation of Re and Os, as well as the inductively coupled plasma mass spectrometry (ICP-MS) analysis of the Re and 
Os concentrations were performed at the Re-Os Isotope Laboratory, National Research Center of Geoanalysis, Chinese Academy of Geological Sciences (CAGS). For the detailed chemical procedure, see Shirey and Walker [51] and Du et al. [52]. Rhenium and Os concentrations and isotopic compositions were measured by a Thermo Fisher Scientific Triton Plus mass spectrometer operating in negative ion detection mode [53]. Instrumental mass fractionation of Os was corrected by normalizing the measured ${ }^{192} \mathrm{Os} /{ }^{188} \mathrm{Os}$ ratio to 3.08271. The analytical reliability was tested by analyses of the JDC standard certified reference material GBW04436.The background values of Re and Os in the whole process were $1.8 \mathrm{pg}$ (uncertainty 0.0003 ) and $0.26 \mathrm{pg}$ (uncertainty 0.0005 ), which were much smaller than the Re and Os contents in the measured samples and the standard samples, so the effect on the experimental results is negligible.

\subsection{LA-ICP-MS Trace Element Analysis of Magnetite}

Trace element analysis of magnetite was conducted by LA-ICP-MS at the Wuhan Sample Solution Analytical Technology Co., Ltd., Wuhan, China. Detailed operating conditions for the laser ablation system and the ICP-MS instrument and data reduction are the same as description by Zong et al. [54]. Laser sampling was performed using a GeolasPro laser ablation system that consists of a COMPexPro 102 ArF excimer laser (wavelength of $193 \mathrm{~nm}$ and maximum energy of $200 \mathrm{~mJ}$ ) and a MicroLas optical system. An Agilent 7700e ICP-MS instrument was used to acquire ion-signal intensities. Helium was applied as a carrier gas. Argon was used as the make-up gas and mixed with the carrier gas via a T-connector before entering the ICP. A "wire" signal smoothing device is included in this laser ablation system [55]. The spot size and frequency of the laser were set to $44 \mu \mathrm{m}$ and $5 \mathrm{~Hz}$, respectively, in this study. Trace element compositions of minerals were calibrated against various reference materials (BHVO-2G, BCR-2G and BIR-1G) without using an internal standard [56]. The actual test results of the standard samples do not deviate from their standard values, ensuring the accuracy of the data of the test samples. Each analysis incorporated a background acquisition of approximately 20-30 s followed by $50 \mathrm{~s}$ of data acquisition from the sample. An Excel-based software ICPMSDataCal was used to perform off-line selection and integration of background and analyzed signals, time-drift correction and quantitative calibration for trace element analysis [56].

\subsection{LA-ICP-MS Trace Element Analysis of Pyrite and Pyrrhotite}

The LA-ICP-MS in situ trace element analysis of sulfides was performed at the State Key Laboratory of Deposit Geochemistry, Institute of Geochemistry, Chinese Academy of Sciences. The laser ablation system is the ASI RESOLution-LR-S155 laser microprobe equipped with the Compex-Pro $193 \mathrm{~nm}$ excimer laser system produced by Coherent. ICP-MS is an Agilent 7700x inductively coupled plasma mass spectrometer. Use helium $(350 \mathrm{~mL} / \mathrm{min}$ ) as the carrier gas. Before leaving the ablation chamber, the aerosol and argon $(900 \mathrm{~mL} / \mathrm{min})$ are mixed as a transport gas. Each acquisition cycle includes about $30 \mathrm{~s}$ of blank signal and $60 \mathrm{~s}$ of sample signal. The diameter of the laser spot beam is 26 microns, the frequency is $5 \mathrm{~Hz}$, and the laser energy is $3 \mathrm{~J} / \mathrm{cm}^{2}$. The internal standard pyrite is used to calibrate the content of $S$ and Fe. The comprehensive data of the content of other elements is calibrated by GSE-1G and GSD-1G. The recommended values of element content in these USGS glasses are based on the GeoReM database (http:/ / georem.mpch-mainz.gwdg.de/ (accessed on 1 January 2021). The sulfide reference MASS-1 was analyzed as an unknown sample to test the accuracy of the experiment.

\section{4. $\mathrm{S}-\mathrm{Pb}$ Isotope}

The $\mathrm{S}$ and $\mathrm{Pb}$ isotope tests of sulfides were completed at the Research Institute of Uranium Geology, Beijing. The sulfides were pulverized to 200 mesh before the test and handpicked under a binocular microscope to ensure a purity of more than $95 \%$. In the $\mathrm{S}$ isotope composition analysis, the sulfides and $\mathrm{Cu}_{2} \mathrm{O}$ were heated under vacuum to form sulfur dioxide, which was then analyzed by a Delta V Plus gas isotope mass 
spectrometer. $\delta^{34} \mathrm{~S}$ values were reported in V-CDT (Vienna standard troilite in Canyon Diablo meteorite) standard, and the test accuracy was about $\pm 0.2 \%$. For the $\mathrm{Pb}$ isotope ratio analysis, the sulfide samples were first leached with hot acid and then tested on an Isoprobe$\mathrm{T}$ hot-surface ionization mass spectrometer using the standard sample NBS981. The $\mathrm{Pb}$ isotope test values are ${ }^{208} \mathrm{~Pb} /{ }^{206} \mathrm{~Pb}=2.1681 \pm 0.0008,{ }^{207} \mathrm{~Pb} /{ }^{206} \mathrm{~Pb}=0.91464 \pm 0.00033$ and ${ }^{204} \mathrm{~Pb} /{ }^{206} \mathrm{~Pb}=0.059042 \pm 0.000037$, respectively, and the test accuracy was higher than $0.08 \%$.

In situ sulfur isotope compositions of pyrite were analyzed using a Nu Plasma II laser-ablation multi-collector inductively coupled plasma mass spectrometer (LA-MC-ICPMS) system, equipped with a Resolution S-155 $193 \mathrm{~nm}$ ArF excimer laser at the State Key Laboratory of Geological Processes and Mineral Resources (GPMR), China University of Geosciences (Wuhan). The laser diameter is $33 \mu \mathrm{m}$ with a laser repetition rate of 8 $\mathrm{Hz}$ for single spot analysis, and the ablation process was set to last for $40 \mathrm{~s}$. The data calibration method used during the test is the "standard-sample-standard" cross-test (SSB). An international sphalerite standard NBS- $123\left(\delta^{34}\right.$ SV-CDT $\left.=17.1 \%\right)$ and an in-house pyrite standard named WS-1, consisting of a natural pyrite crystal from the Wenshan polymetallic skarn deposit in Yunnan Province in South China, is used to calibrate the mass bias for $\mathrm{S}$ isotopes. The $\delta^{34}$ SV-CDT values $(1.1 \% \pm 0.2 \%$ ) of WS- 1 were determined with SIMS at the Chinese Academy of Geochemistry, Guangzhou [57]. To monitor the accuracy of the data, a pair of laboratory internal standards were tested every 8 sample inserts. The actual test results of the standard samples do not deviate from their standard values, ensuring the accuracy of the data of the test samples. The true sulfur isotope ratio of unknown samples was calculated by correction for instrumental mass bias by linear interpolation between the biases calculated from two neighboring standard analyses. The analytical precision is about $\pm 0.3 \%$.

\section{Results}

\subsection{Pyrite Re-Os Dating}

The Re-Os isotopic data of eight pyrite samples from the Weizigou deposit are presented in Table 1. The Re and ${ }^{187}$ Re concentrations range from 0.383 to $9.463 \mathrm{ng} / \mathrm{g}$ and 0.241 to $5.951 \mathrm{ng} / \mathrm{g}$, while the common Os and ${ }^{187}$ Os concentrations range from 0.0010 to $0.0382 \mathrm{ng} / \mathrm{g}$ and 0.0017 to $0.0758 \mathrm{ng} / \mathrm{g}$, respectively. The ${ }^{187} \mathrm{Re} /{ }^{188} \mathrm{Os}$ and ${ }^{187} \mathrm{Os} /{ }^{188} \mathrm{Os}$ ratios are 432-6894 and 10.92-33.59, respectively. The eight samples yielded an isochron age of $196 \pm 110 \mathrm{Ma}$ (Figure 5a). Excluding four distinct samples, four samples that yielded a revised isochron age of $197 \pm 11 \mathrm{Ma}(\mathrm{MSWD}$ (mean squared weighted deviation) $=50$ ) (Figure $5 b)$ remained, with an $\left.\left({ }^{187} \mathrm{Os} /{ }^{188} \mathrm{Os}\right)\right)_{\mathrm{i}}$ of $11.15 \pm 0.79$.

Table 1. Re-Os compositions of pyrite from the Weizigou deposit.

\begin{tabular}{|c|c|c|c|c|c|c|c|c|c|c|c|c|c|}
\hline \multirow{2}{*}{$\begin{array}{c}\text { Samples } \\
\text { No. }\end{array}$} & \multirow{2}{*}{$\begin{array}{c}\text { Samples } \\
\text { Weight (g) }\end{array}$} & \multicolumn{2}{|c|}{$\operatorname{Re}$ Conc (ppb) } & \multicolumn{2}{|c|}{ Os Conc (ppb) } & \multicolumn{2}{|c|}{${ }^{187} \operatorname{Re}$ Conc (ppb) } & \multicolumn{2}{|c|}{${ }^{187}$ Os Conc (ppb) } & \multicolumn{2}{|c|}{${ }^{187} \mathrm{Re} /{ }^{188} \mathrm{Os}$} & \multicolumn{2}{|c|}{${ }^{187} \mathrm{Os} /{ }^{188} \mathrm{Os}$} \\
\hline & & Value & $\sigma$ & Value & $\sigma$ & Value & $\sigma$ & Value & $\sigma$ & Value & $\sigma$ & Value & $\sigma$ \\
\hline WZG7-4 & 0.65037 & 2.222 & 0.017 & 0.0249 & 0.0002 & 1.396 & 0.010 & 0.0401 & 0.0003 & 432 & 4.6 & 12.40 & 0.03 \\
\hline WZG7-5 & 0.65044 & 1.775 & 0.013 & 0.0012 & 0.0000 & 1.116 & 0.008 & 0.0055 & 0.0000 & 6894 & 77 & 33.59 & 0.17 \\
\hline WZG7-6 & 0.65056 & 3.669 & 0.027 & 0.0127 & 0.0001 & 2.306 & 0.017 & 0.0199 & 0.0002 & 1396 & 15 & 12.06 & 0.03 \\
\hline WZG7-7 & 0.65038 & 1.600 & 0.012 & 0.0012 & 0.0000 & 1.006 & 0.007 & 0.0051 & 0.0000 & 6370 & 74 & 32.23 & 0.18 \\
\hline WZG7-8 & 0.30063 & 1.663 & 0.012 & 0.0037 & 0.0000 & 1.045 & 0.008 & 0.0052 & 0.0000 & 2189 & 23 & 10.92 & 0.04 \\
\hline WZG7-9 & 0.65026 & 9.463 & 0.072 & 0.0382 & 0.0003 & 5.951 & 0.045 & 0.0758 & 0.0006 & 1198 & 12 & 15.26 & 0.03 \\
\hline WZG7-10 & 0.65020 & 5.267 & 0.039 & 0.0230 & 0.0002 & 3.310 & 0.025 & 0.0676 & 0.0005 & 1108 & 11 & 22.63 & 0.04 \\
\hline WZG10-2 & 0.65065 & 0.383 & 0.003 & 0.0010 & 0.0000 & 0.241 & 0.002 & 0.0017 & 0.0006 & 1946 & 20 & 13.36 & 0.04 \\
\hline
\end{tabular}

\subsection{LA-ICP-MS Trace Element Analysis of Magnetite}

The LA-ICP-MS test data samples of the Weizigou deposit are shown in Table 2, with a total of 25 points tested. The concentrations of trace elements in different types of magnetite are quite different. The elements detected in magnetite include lithophile elements $\mathrm{Si}, \mathrm{Ga}, \mathrm{Mg}, \mathrm{Mn}, \mathrm{Al}, \mathrm{Ga}, \mathrm{Rb}$ and $\mathrm{Sr}$ as well as siderophile elements $\mathrm{Ti}, \mathrm{Cr}, \mathrm{Ni}$ and $\mathrm{V}$. The contents of siderophile elements $\mathrm{Ti}, \mathrm{Cr}, \mathrm{V}$ and $\mathrm{Ni}$ in Mag-II-A are generally lower, 
with a Ti content of 753-1073 ppm with an average of $880 \mathrm{ppm}$, a Cr content of 77-288 ppm with an average of $149 \mathrm{ppm}$, a $\mathrm{V}$ content of $16-21 \mathrm{ppm}$ with an average of $18 \mathrm{ppm}$, a Ni content of 11-56 ppm with an average of $23 \mathrm{ppm}$ and a Si content of 1400-2987 ppm with an average of $1973 \mathrm{ppm}$. The content of lithophile elements such as $\mathrm{Mg}, \mathrm{Al}, \mathrm{Ca}, \mathrm{Mn}$ and $\mathrm{Na}$ is significantly lower, with a $\mathrm{Mg}$ content of $66-552 \mathrm{ppm}$ with an average of $226 \mathrm{ppm}$, an $\mathrm{Al}$ content of 2915-5406 ppm with an average of $4152 \mathrm{ppm}$, a Ca content of 0-1714 ppm with an average of $227 \mathrm{ppm}$, a Mn content of 154-277 ppm with an average of $211 \mathrm{ppm}$ and a $\mathrm{Na}$ content of 0-19 ppm with an average of $7 \mathrm{ppm}$.
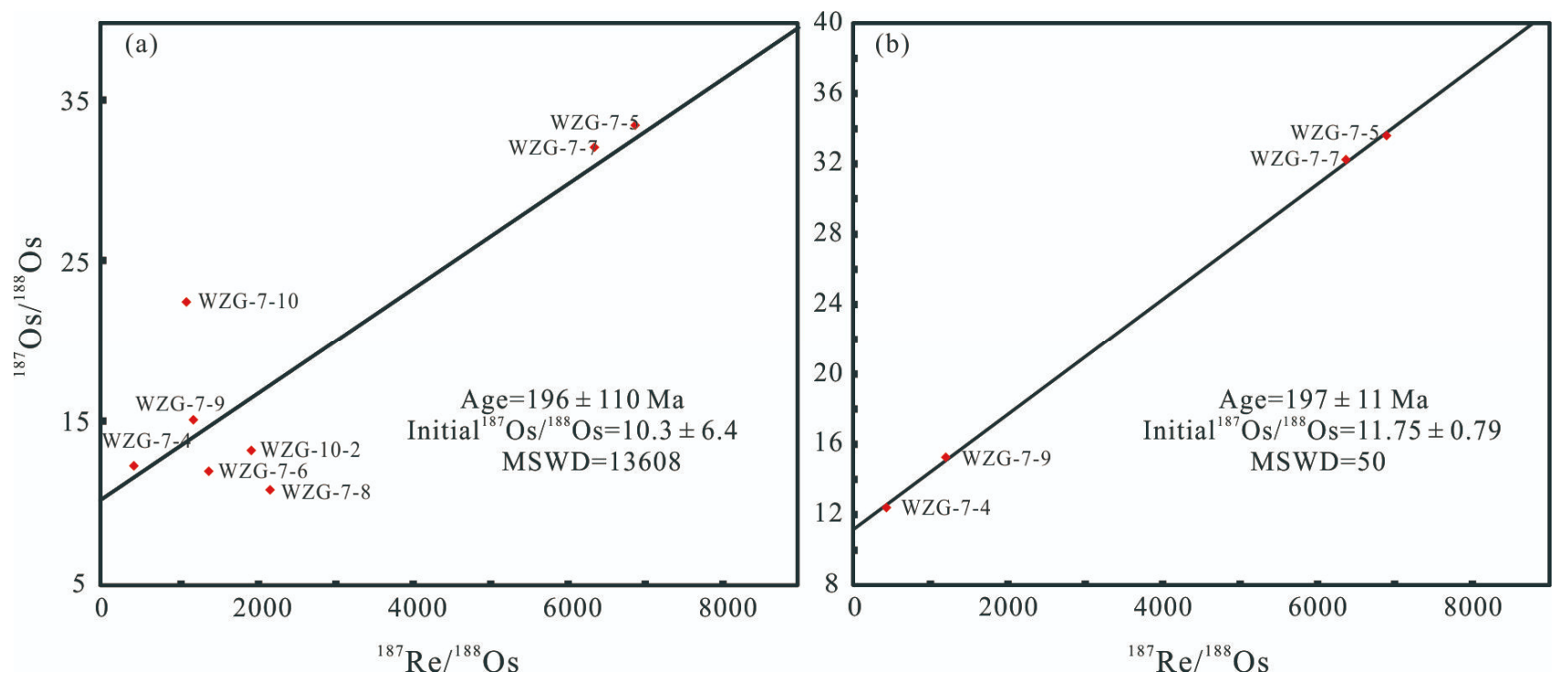

Figure 5. (a) Re-Os isochron age diagram of all samples; (b) Re-Os isochron age diagram after excluding four samples with large deviations.

Table 2. LA-ICP-MS results of trace elements (in ppm) of magnetite from the Weizigou deposit.

\begin{tabular}{|c|c|c|c|c|c|c|c|c|c|c|c|c|c|c|}
\hline Sample & Types & No. & $\mathrm{Mg}$ & Al & Si & $\mathrm{Ca}$ & $\mathrm{Ti}$ & $\mathbf{V}$ & $\mathrm{Cr}$ & Mn & Co & $\mathrm{Ni}$ & $\mathrm{Cu}$ & $\mathrm{Zn}$ \\
\hline \multirow[t]{15}{*}{ WZG-12-2 } & Mag-II-A & 1 & 159.51 & 3154.18 & 1512.28 & 19.29 & 798.7 & 18.5 & 288.33 & 168.92 & 9.93 & 13.35 & 0 & 81.52 \\
\hline & & 2 & 348.74 & 4651.57 & 2538.21 & 72.11 & 922.18 & 16.73 & 185.87 & 240.33 & 11.59 & 11.2 & 0.73 & 325.28 \\
\hline & & 3 & 119.82 & 3060.06 & 1872.74 & 0 & 834.55 & 16.07 & 77.62 & 174.57 & 8.91 & 31.97 & 0 & 21.92 \\
\hline & & 4 & 213.89 & 5422.75 & 1634.58 & 15.4 & 902.78 & 16.18 & 189.91 & 274.49 & 12.61 & 55.85 & 0.48 & 189.19 \\
\hline & & 5 & 168.37 & 3987.95 & 1912.87 & 76.27 & 934.76 & 18.33 & 145.52 & 203.33 & 11.35 & 22.9 & 0 & 60.44 \\
\hline & & 6 & 208.78 & 4372.47 & 1383.45 & 630.53 & 906.17 & 19 & 148.72 & 228.49 & 11.52 & 38.38 & 0 & 119.77 \\
\hline & & 7 & 113.41 & 2918.67 & 2260.75 & 0 & 787.47 & 19.56 & 123.73 & 172.03 & 10.92 & 17.28 & 0 & 45.44 \\
\hline & & 8 & 64.34 & 2427.54 & 1552.11 & 0 & 753.3 & 18.95 & 172.48 & 161.65 & 10.31 & 0 & 1.56 & 8.57 \\
\hline & & 9 & 208.17 & 4169.59 & 2246.09 & 0 & 923.04 & 18.11 & 113.86 & 151.09 & 10.77 & 29.74 & 0 & 105.48 \\
\hline & & 10 & 552.32 & 5066.33 & 3009.29 & 225.03 & 914.92 & 17.45 & 144.26 & 249.5 & 11.51 & 33.42 & 1.13 & 314.78 \\
\hline & & 11 & 140.13 & 4483.02 & 1871.34 & 333.65 & 912.78 & 18.86 & 159.39 & 223.25 & 12.26 & 0 & 1.91 & 117.63 \\
\hline & & 12 & 145.44 & 5146.71 & 1812.78 & 0 & 928.44 & 16.58 & 126.84 & 240.81 & 13.07 & 0 & 0 & 141.2 \\
\hline & & 13 & 104.15 & 3950.7 & 1716.89 & 0 & 769.1 & 16.41 & 134.97 & 195.37 & 12.43 & 35.13 & 0 & 72.41 \\
\hline & & 14 & 483.24 & 4569.37 & 2147.74 & 306.6 & 920.09 & 17.44 & 115.8 & 249.36 & 12.99 & 39.05 & 1.04 & 302.79 \\
\hline & & 15 & 349.52 & 4805.98 & 2204.55 & 1718.48 & 1073.44 & 21.41 & 104.51 & 229.64 & 14.12 & 23.57 & 1.34 & 159.92 \\
\hline \multirow[t]{10}{*}{ WZG-1-2 } & Mag-II-B & 1 & 397.38 & $12,372.09$ & 669.4 & 36.28 & 4107.69 & 80.54 & 9.88 & 1368.67 & 15.87 & 1.7 & 0.26 & 474.38 \\
\hline & & 2 & 228.06 & 8196.11 & 1977.29 & 70.82 & 4216.18 & 86.01 & 13.27 & 1147.33 & 13.34 & 2.02 & 0 & 267.43 \\
\hline & & 3 & 218.16 & 9657.02 & 1504.31 & 3.04 & 4120.99 & 82.91 & 12.13 & 1206.15 & 13.82 & 1.24 & 0 & 357.02 \\
\hline & & 4 & 332.15 & $10,675.81$ & 2537.01 & 50.74 & 4153.37 & 81.92 & 12.91 & 1286.17 & 15.39 & 1.55 & 0 & 390.26 \\
\hline & & 5 & 243.77 & 9173.97 & 2208.96 & 59.39 & 4279.17 & 82.21 & 13.92 & 1138.65 & 14.52 & 1.73 & 0.16 & 443.5 \\
\hline & & 6 & 382.92 & 3802.58 & 4123.46 & 138.47 & 4055.02 & 87.77 & 25.83 & 786.59 & 9.59 & 0.98 & 0.4 & 72.53 \\
\hline & & 7 & 370.23 & 5423.39 & 3755.84 & 26.67 & 4036.41 & 82.1 & 22.08 & 978.09 & 10.8 & 1.08 & 0 & 94.83 \\
\hline & & 8 & 389.56 & 9109.79 & 2259.98 & 99.33 & 4200.97 & 80.18 & 15.18 & 1228.83 & 14.06 & 1.5 & 0.15 & 429.13 \\
\hline & & 9 & 312.84 & 8380.16 & 2143.38 & 25.89 & 4206.48 & 87.2 & 15.47 & 1015.38 & 12.94 & 1.7 & 0.1 & 409.35 \\
\hline & & 10 & 114.97 & 6194.97 & 1693.53 & 0 & 4280.88 & 95.66 & 14.27 & 774.05 & 10.79 & 1.19 & 0.2 & 201.16 \\
\hline
\end{tabular}

Compared with Mag-II-A, the content of Ti, Mn and V in Mag-II-B is higher, while the content of $\mathrm{Ni}$ and $\mathrm{Cr}$ is lower. Nevertheless, there is little difference in the contents of the other elements. The content of each element in Mag-II-B is as follows: Ti, 4036-4281 ppm with an average of $4166 \mathrm{ppm}$; $\mathrm{Cr}, 9.9-25.8 \mathrm{ppm}$ with an average of $15.5 \mathrm{ppm}$; 
$\mathrm{V}, 80.5-95.7 \mathrm{ppm}$ with an average of $84.7 \mathrm{ppm} ; \mathrm{Ni}, 1.0-2.0 \mathrm{ppm}$ with an average of $1.5 \mathrm{ppm}$; $\mathrm{Si}, 669.4-4123.4 \mathrm{ppm}$ with an average of $2287.3 \mathrm{ppm} ; \mathrm{Mg}$, 115.0-397.4 ppm with an average of $299.0 \mathrm{ppm}$; Al, 3803-12,372 ppm with an average of $8299 \mathrm{ppm}$; Ca, $0-138.5 \mathrm{ppm}$ with an average of $51.1 \mathrm{ppm}$; Mn, 774-1286 ppm with an average of $1093 \mathrm{ppm} ; \mathrm{Na}, 0.9-45.7 \mathrm{ppm}$ with an average of $11.0 \mathrm{ppm}$.

\subsection{LA-ICP-MS Trace Element Analysis of Pyrite and Pyrrhotite}

The LA-ICP-MS test data of two different types of pyrite are shown in Table 3. A total of 43 points were tested. The results show that the concentrations of most elements in the two types of pyrite are higher than the minimum detection value, while the concentrations of $\mathrm{V}, \mathrm{Cr}$ and $\mathrm{Mn}$ in some pyrite particles are lower than the minimum detection value values. The contents of most trace elements in the two pyrites showed regular changes (Figure 6). Among them, Co is the element with the highest content in all pyrites. Its content in Py-II is 125.0-1777.2 ppm, with an average of 692.7 ppm; in Py-III, its content is 320.4-437.8 ppm, with an average of 375.4 ppm. Ni and Mn are enriched in Py-II and Py-III (the content of Ni in Py-I is 15.3-620.7 ppm, while the content of Mn is 0.0-449.0 ppm). In addition, all pyrites contain Ti (1.9-26.5 ppm in Py-II; 1.7-2.4 ppm in Py-III) and Ge (1.2-10.3 ppm in Py-II; 0.8-1.4 ppm in Py-III).

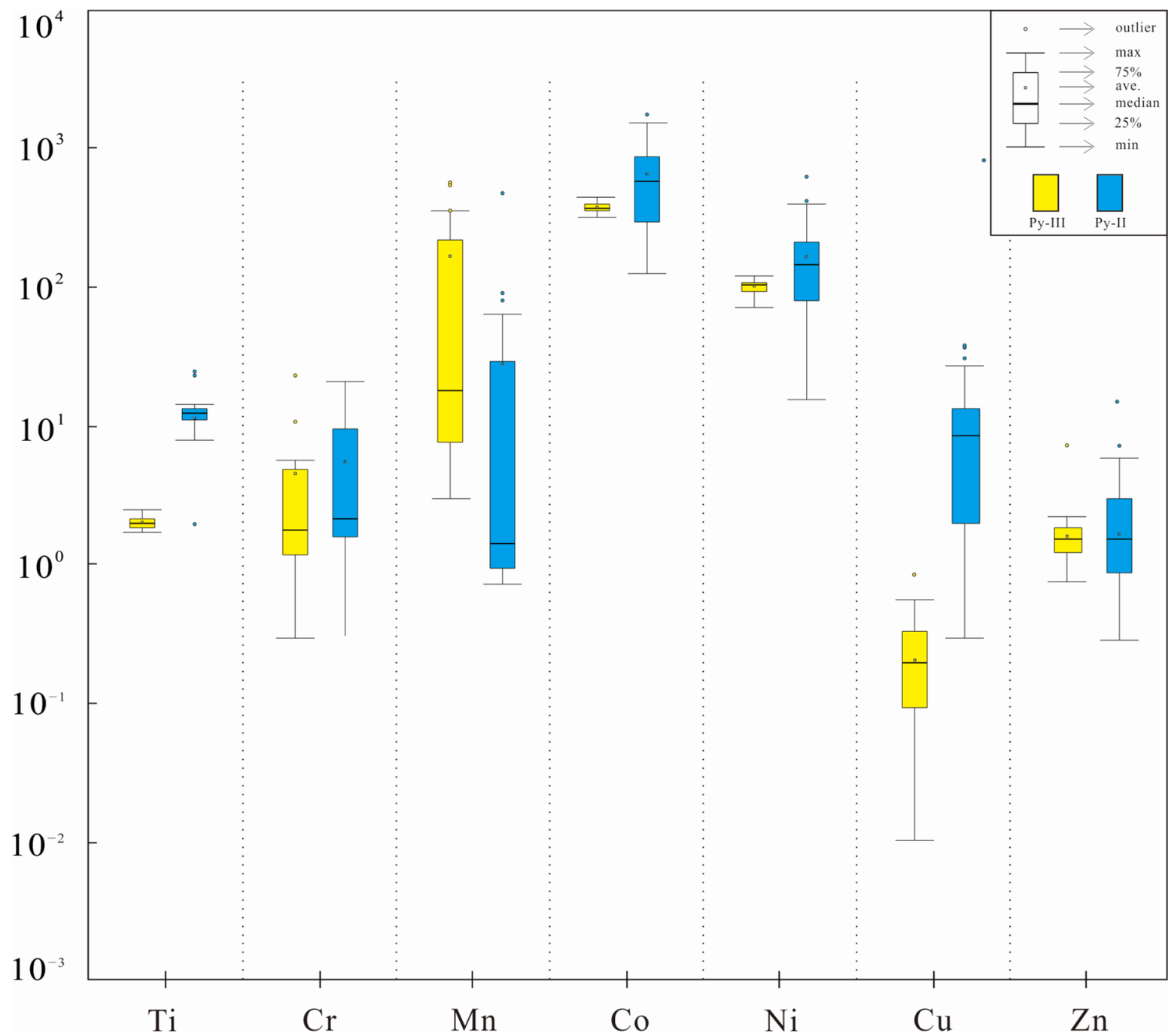

Figure 6. Box and whisker plots of trace element concentrations ( $\mathrm{Ti}, \mathrm{Cr}, \mathrm{Mn}, \mathrm{Co}, \mathrm{Ni}, \mathrm{Cu}$ and $\mathrm{Zn}$ ) determined using LA-ICPMS for different types of pyrite in the Weizigou deposit. 
Table 3. LA-ICP-MS results of trace elements (in ppm) of pyrite and pyrrhotite from the Weizigou deposit.

\begin{tabular}{|c|c|c|c|c|c|c|c|c|c|c|c|c|c|c|c|c|}
\hline Types & Sample & No. & $\mathrm{Ti}$ & V & $\mathrm{Cr}$ & Mn & Co & $\mathrm{Ni}$ & $\mathrm{Cu}$ & Zn & Ga & $\mathrm{Ge}$ & As & Se & $\mathrm{Pb}$ & Bi \\
\hline \multirow[t]{18}{*}{ Py-II } & WZG-1-2 & 1 & 9.25 & 0.18 & 0.31 & 92.58 & 217.64 & 15.34 & 12.67 & 3.63 & 1.82 & 1.19 & 17.33 & 16.6 & 8.44 & 41.31 \\
\hline & & 2 & 7.86 & 0.08 & 0.43 & 63.76 & 170.77 & 41.61 & 15.84 & 2.2 & 0.09 & 1.25 & 6.8 & 0 & 7.22 & 5.87 \\
\hline & & 3 & 1.91 & 0 & 2.17 & 29.04 & 298.15 & 59.85 & 8.62 & 0.94 & 0.07 & 1.23 & 2.6 & 0 & 5.16 & 4.16 \\
\hline & WZG-6-5 & 4 & 12.93 & 0.09 & 0 & 0.87 & 891.72 & 196.49 & 0.33 & 0.83 & 0 & 9.05 & 6.41 & 4.14 & 0.95 & 0.01 \\
\hline & & 5 & 13.62 & 0 & 0 & 0.93 & 649.65 & 145.4 & 4.36 & 0.78 & 0 & 9.61 & 6.17 & 5.75 & 0.92 & 0.03 \\
\hline & & 6 & 13.3 & 0 & 0 & 0.91 & 886.46 & 200.16 & 3.08 & 1.99 & 0.03 & 9.16 & 5.18 & 4.85 & 4.47 & 0.02 \\
\hline & & 7 & 12.45 & 0.09 & 0 & 0 & 396.65 & 112.78 & 0 & 0.64 & 0.1 & 9.4 & 6.32 & 0 & 0.72 & 0.02 \\
\hline & & 8 & 14.72 & 0.12 & 0 & 1.9 & 220.36 & 84.55 & 9.27 & 4 & 0.06 & 9.8 & 6.24 & 4.35 & 2.13 & 1.09 \\
\hline & & 9 & 12.98 & 0.12 & 0 & 1.11 & 124.98 & 40.05 & 20.7 & 3.03 & 0.03 & 9.92 & 5.81 & 0 & 0.44 & 0.08 \\
\hline & & 10 & 12.48 & 0.13 & 1.61 & 0.88 & 579.92 & 175.69 & 0 & 0.95 & 0.02 & 9.79 & 5.42 & 4.81 & 0.51 & 0.03 \\
\hline & & 11 & 11.13 & 0.12 & 0 & 0 & 441.03 & 144.49 & 0.3 & 2.93 & 0.02 & 9.72 & 5.38 & 3.97 & 0.51 & 0.03 \\
\hline & & 12 & 11.01 & 0 & 0 & 4.58 & 809.54 & 184.71 & 11.14 & 1.16 & 0.06 & 9.54 & 6.14 & 5.28 & 4.61 & 0.12 \\
\hline & & 13 & 12.59 & 0 & 0 & 34.56 & 548.17 & 140.23 & 812.33 & 4.74 & 0.27 & 9.99 & 11.34 & 0 & 8.02 & 0.13 \\
\hline & & 14 & 12.5 & 0.1 & 0 & 1.08 & 393.18 & 103.34 & 2.52 & 0.39 & 0.07 & 9.52 & 6.95 & 5.24 & 0.77 & 0.04 \\
\hline & & 15 & 13.25 & 0.09 & 0 & 0.91 & 654.48 & 171.1 & 9.76 & 0 & 0 & 9.3 & 4.85 & 5.04 & 3.04 & 0.03 \\
\hline & & 16 & 13.2 & 0 & 0 & 0 & 864.18 & 241.04 & 0.99 & 0 & 0.04 & 9.48 & 6.49 & 6.27 & 6.34 & 0.03 \\
\hline & & 17 & 14.1 & 0.13 & 4.78 & 0 & 140.23 & 44.42 & 33.08 & 4.82 & 0 & 9.51 & 7.58 & 4.32 & 3.92 & 4.57 \\
\hline & & 18 & 24.6 & 0.84 & 0 & 449 & 184.86 & 63.72 & 46.16 & 5.87 & 1.62 & 10.29 & 6.94 & 0 & 9.74 & 15.78 \\
\hline \multirow[t]{15}{*}{ Py-II } & WZG-6-5 & 19 & 11.03 & 0.14 & 0 & 1.37 & 1333.6 & 329.65 & 13.14 & 2.68 & 0.08 & 9.37 & 7.43 & 7.62 & 9.9 & 3.88 \\
\hline & & 20 & 26.53 & 0.84 & 20.87 & 79.57 & 807.36 & 187.54 & 42.84 & 14.76 & 2.44 & 9.64 & 10.13 & 4.91 & 9.83 & 21.08 \\
\hline & & 21 & 14.6 & 0 & 0 & 4.53 & 1053 & 255.12 & 3.92 & 1.56 & 0.1 & 9.85 & 6.94 & 6.55 & 4.15 & 2.48 \\
\hline & & 22 & 13.19 & 0 & 3.11 & 5.98 & 612.34 & 150.6 & 3.09 & 1.27 & 0.12 & 9.19 & 6.73 & 5.12 & 2.71 & 1.2 \\
\hline & & 23 & 9.14 & 0.52 & 17.4 & 44.78 & 529.46 & 122.74 & 10.78 & 7.56 & 1.67 & 9.63 & 5.59 & 5.64 & 5.31 & 13.98 \\
\hline & & 24 & 11.03 & 0 & 0 & 0 & 845.52 & 208.81 & 1.99 & 0.42 & 0.02 & 9.49 & 4.73 & 5.62 & 5.66 & 0.06 \\
\hline & & 25 & 11.18 & 0 & 0 & 0.73 & 1531.9 & 360.42 & 10.97 & 1.02 & 0 & 9.37 & 4.98 & 11.47 & 38.93 & 0.23 \\
\hline & & 26 & 11.2 & 0.08 & 0 & 1.51 & 1346.88 & 395.66 & 5.75 & 0.87 & 0.07 & 9.27 & 6.52 & 8.81 & 5.73 & 4.01 \\
\hline & & 27 & 10.12 & 0.14 & 1.75 & 8.57 & 1431.22 & 408.41 & 26.74 & 1.67 & 0.3 & 8.82 & 7.33 & 6.11 & 9.53 & 24.58 \\
\hline & & 28 & 9.43 & 0 & 0 & 0.99 & 1253.1 & 320.06 & 1.91 & 0 & 0 & 8.28 & 5.64 & 6.75 & 2.68 & 0.17 \\
\hline & & 29 & 10.34 & 0 & 9.48 & 1.14 & 1777.16 & 620.72 & 10.67 & 1.52 & 0.07 & 9.05 & 6.53 & 8.1 & 12.51 & 0.56 \\
\hline & & 30 & 12.73 & 0 & 0 & 1.19 & 464.61 & 107.1 & 4.49 & 1.84 & 0.05 & 9.43 & 8.29 & 3.76 & 3.61 & 1.19 \\
\hline & & 31 & 8.9 & 0.08 & 0 & 0.78 & 331.08 & 59.12 & 0.52 & 0.58 & 0 & 8.68 & 3.26 & 1.93 & 0.73 & 0.01 \\
\hline & & 32 & 11.3 & 0.08 & 1.57 & 0 & 278.04 & 79.78 & 0.8 & 0.28 & 0.03 & 9.01 & 4.19 & 2.26 & 1.03 & 0.07 \\
\hline & & 33 & 13.14 & 0.19 & 0 & 0 & 273.81 & 63.42 & 1.14 & 1.3 & 0.03 & 9.53 & 4.04 & 4.76 & 0.95 & 0.06 \\
\hline \multirow[t]{8}{*}{ Py-III } & WZG-12-2 & 1 & 2.05 & 0.02 & 10.44 & 7.75 & 423.13 & 105.83 & 0.43 & 1.84 & 0.06 & 1.25 & 0.25 & 1.52 & 2.23 & 4.54 \\
\hline & & 2 & 2 & 0 & 2.36 & 4.24 & 398.84 & 105.99 & 0.23 & 1.67 & 0.02 & 1.4 & 0.16 & 4.5 & 1.31 & 4.25 \\
\hline & & 3 & 2.11 & 0.02 & 4.82 & 598.26 & 437.75 & 120.94 & 0.55 & 1.84 & 0.19 & 1.1 & 0.59 & 20.9 & 1.49 & 2.98 \\
\hline & & 4 & 1.86 & 0.01 & 3.21 & 64.7 & 365.09 & 72.14 & 0.08 & 1.61 & 0.03 & 1.07 & 0.38 & 4.65 & 0.61 & 2.19 \\
\hline & & 5 & 2.15 & 0.01 & 25.11 & 7.71 & 410.13 & 117.09 & 0.33 & 2.22 & 0.01 & 1.45 & 0.49 & 0 & 3.56 & 8.09 \\
\hline & & 6 & 1.84 & 0.01 & 1.18 & 38.73 & 383.77 & 112.18 & 0.84 & 7.55 & 0.02 & 1.09 & 0.4 & 4.55 & 0.79 & 1.77 \\
\hline & & 7 & 1.93 & 0 & 1.18 & 354.36 & 363.93 & 106.07 & 0.2 & 1.52 & 0.13 & 0.99 & 0.52 & 12.14 & 3.96 & 6.68 \\
\hline & & 8 & 1.73 & 0.01 & 1.75 & 15.11 & 387.2 & 88.66 & 0.09 & 1.57 & 0 & 1.19 & 0.09 & 1.98 & 0.7 & 1.52 \\
\hline \multirow[t]{8}{*}{ Po } & WZG-6-5 & 18 & 11.13 & 0 & 0 & 0 & 484.55 & 156.2 & 3.25 & 1.24 & 0.06 & 10.97 & 13.47 & 6.88 & 0.91 & 1.15 \\
\hline & & 19 & 6.86 & 0 & 0 & 2.94 & 525.22 & 159.17 & 5.87 & 1.36 & 0.06 & 10.98 & 13.62 & 8.75 & 0.82 & 0.51 \\
\hline & & 20 & 14.99 & 0.28 & 0 & 0 & 520.98 & 161.27 & 6.57 & 15.81 & 0.1 & 12.23 & 16.71 & 11.52 & 0.84 & 0.6 \\
\hline & & 21 & 9.01 & 0 & 4.65 & 0 & 506.15 & 161.23 & 7.33 & 1.92 & 0 & 11.29 & 13.38 & 5.42 & 1.01 & 0.62 \\
\hline & & 22 & 6.57 & 0.27 & 0 & 3.07 & 533.83 & 160.21 & 5.29 & 0 & 0 & 12.39 & 13.16 & 5.82 & 1.16 & 0.91 \\
\hline & & 23 & 8.02 & 0 & 0 & 0 & 539.96 & 164.98 & 7.81 & 0 & 0 & 12.42 & 15.13 & 7.94 & 0.72 & 0.51 \\
\hline & & 24 & 7.52 & 0 & 0 & 0 & 498.43 & 158.24 & 5.7 & 7.74 & 0.07 & 11.18 & 15.14 & 7.91 & 1.05 & 1.15 \\
\hline & & 25 & 15.32 & 0.33 & 0 & 0 & 510.59 & 159.13 & 2.05 & 0 & 0.09 & 10.7 & 14.63 & 6.34 & 1.35 & 1.57 \\
\hline
\end{tabular}

The LA-ICP-MS test data of pyrrhotite from the Weizigou gold deposit are shown in Table 3. A total of 25 points were tested. The content of some elements in pyrrhotite changes as follows: $\mathrm{Co}, 481.2-554.0 \mathrm{ppm}$ with an average of $518.3 \mathrm{ppm} ; \mathrm{Ni}, 148.8-242.5 \mathrm{ppm}$ with an average of $165.5 \mathrm{ppm} ; \mathrm{Cu}, 1.5-41.1 \mathrm{ppm}$ with an average of $9.5 \mathrm{ppm}$. The content of some elements, such as $\mathrm{Ti}$ (3.6-15.3 ppm with an average of $9.0 \mathrm{ppm}), \mathrm{Zn}(0.0-15.8 \mathrm{ppm}$ with an average of $3.0 \mathrm{ppm})$, As (9.3-20. $9 \mathrm{ppm}$ with an average of $16.0 \mathrm{ppm})$ and Se (0.0-12.1 ppm with an average of $5.0 \mathrm{ppm})$, is relatively uniform.

\subsection{Sulfur and Lead Isotopes}

The sulfur and lead isotopic compositions of pyrite are listed in Table 4 . The $\delta^{34} \mathrm{SV}$-CDT values range from $4.70 \%$ to $11.80 \%$ (avg. $8.84 \%$ ). Pyrite has values of ${ }^{206} \mathrm{~Pb} / 204 \mathrm{~Pb}=18.605-20.136$ (avg. 19.211), ${ }^{207} \mathrm{~Pb} /{ }^{204} \mathrm{~Pb}=15.637-15.710$ (avg. 15.657) and ${ }^{208} \mathrm{~Pb} /{ }^{204} \mathrm{~Pb}=38.534-39.129$ (avg. 38.777). The $\delta^{34}$ SV-CDT values of granitic gneiss and meta-gabbro range from $7.44 \%$ to $8.44 \%$ o (avg. $7.96 \%$ ) and $4.34 \%$ to $10.54 \%$ o (avg. $6.55 \%$ ), respectively. 
Table 4. Sulfur and lead isotopic compositions from the Weizigou deposit.

\begin{tabular}{|c|c|c|c|c|c|c|c|c|}
\hline Sample No. & Mineral & $\mathcal{\delta}^{34} S_{\mathrm{V}-\mathrm{CDT}}(\%)$ & ${ }^{206} \mathrm{~Pb} /{ }^{204} \mathrm{~Pb}$ & $2 \sigma$ & ${ }^{207} \mathrm{~Pb} /{ }^{204} \mathrm{~Pb}$ & $2 \sigma$ & ${ }^{208} \mathrm{~Pb} /{ }^{204} \mathrm{~Pb}$ & $2 \sigma$ \\
\hline WZG-7-4 & Pyrite & 11.8 & 18.634 & 0.002 & 15.638 & 0.001 & 38.591 & 0.004 \\
\hline WZG-7-7 & Pyrite & 9.9 & 18.605 & 0.004 & 15.648 & 0.005 & 38.671 & 0.01 \\
\hline WZG-7-8 & Pyrite & 7.9 & 19.963 & 0.003 & 15.653 & 0.003 & 39.129 & 0.007 \\
\hline WZG-7-10 & Pyrite & 4.7 & 20.136 & 0.002 & 15.71 & 0.002 & 38.962 & 0.005 \\
\hline WZG-10-2 & Pyrite & 9.9 & 18.718 & 0.002 & 15.637 & 0.002 & 38.534 & 0.004 \\
\hline WZG-2-1 & Granitic gneiss & 7.44 & & & & & & \\
\hline WZG-2-4 & Granitic gneiss & 8.44 & & & & & & \\
\hline WZG-2-5 & Granitic gneiss & 7.99 & & & & & & \\
\hline WZG-5-5 & Meta-gabbro & 4.74 & & & & & & \\
\hline WZG-11-1 & Meta-gabbro & 10.54 & & & & & & \\
\hline WZG-20-3 & Meta-gabbro & 4.37 & & & & & & \\
\hline
\end{tabular}

In situ sulfur isotopic compositions are presented in Table 5. The $\delta^{34}$ SV-CDT values of pyrite (Py-II), pyrrhotite, and chalcopyrite range from $11.41 \%$ o to $12.89 \%$ o (avg. $12.05 \%$ o), $11.60 \%$ o to $12.08 \%$ o (avg. $11.93 \%$ ) and $12.24 \%$ o to $12.83 \%$ (avg. $12.59 \%$ ), respectively.

Table 5. In situ sulfur isotopic compositions of sulfides from the Weizigou deposit.

\begin{tabular}{ccc}
\hline Sample No. & Mineral & $\mathbf{\delta}^{\mathbf{3 4}} \mathbf{S}_{\mathbf{V}-\mathbf{C D T}} \mathbf{( \% \mathbf { o } )}$ \\
\hline WZG-7-1-01 & Pyrite & 11.58 \\
WZG-7-1-02 & Pyrite & 12.31 \\
WZG-7-1-03 & Pyrite & 11.9 \\
WZG-10-1-01 & Pyrite & 11.79 \\
WZG-10-1-02 & Pyrite & 12.89 \\
WZG-10-1-03 & Pyrite & 11.82 \\
WZG-10-1-01 & Chalcopyrite & 12.83 \\
WZG-10-1-02 & Chalcopyrite & 12.76 \\
WZG-10-1-03 & Chalcopyrite & 12.52 \\
WZG-10-1-04 & Chalcopyrite & 12.24 \\
WZG-10-1-05 & Chalcopyrite & 12.58 \\
WZG-12-1-01 & Pyrite & 11.41 \\
WZG-12-1-02 & Pyrite & 12.04 \\
WZG-12-1-03 & Pyrite & 12.19 \\
WZG-12-1-04 & Pyrite & 12.48 \\
WZG-12-1-05 & Pyrite & 12.14 \\
WZG-12-1-06 & Pyrite & 12.04 \\
WZG-10-1-01 & Pyrrhotite & 11.99 \\
WZG-10-1-02 & Pyrrhotite & 12.08 \\
WZG-10-1-03 & Pyrrhotite & 12.02 \\
WZG-12-1-01 & Pyrrhotite & 12.01 \\
WZG-12-1-02 & Pyrrhotite & 11.6 \\
WZG-12-1-03 & Pyrrhotite & 11.87 \\
\hline
\end{tabular}

\section{Discussion}

\subsection{Magnetite Genetic Type}

Magnetite is widely present in magmatic, metamorphic, and sedimentary rocks, as well as various types of mineral deposits [58,59]. The analysis of the composition of magnetite can reveal the physical and chemical conditions of its formation. In addition to iron, the trace elements that are usually present in the structure of magnetite also include $\mathrm{Mg}, \mathrm{Al}, \mathrm{Sc}, \mathrm{Ti}, \mathrm{V}, \mathrm{Cr}, \mathrm{Mn}, \mathrm{Co}, \mathrm{Ni}, \mathrm{Zn}, \mathrm{Ga}, \mathrm{Ge}, \mathrm{Y}, \mathrm{Hf}, \mathrm{Nb}, \mathrm{Mo}$, Ta and Zr [60-64]. These trace elements can be used to explain the genesis of rocks and can be indicative of mineral exploration [64-72]. The concentration of trace elements in magnetite depends on many factors, including the similarity of the ionic radius and cation valence, oxygen fugacity $\left(f_{\mathrm{O} 2}\right)$, magma/fluid composition and temperature $[63,73-76]$. 
Temperature is the main factor controlling the composition of magnetite. Under hightemperature conditions, elements such as $\mathrm{Al}$ and $\mathrm{Ti}$ are more likely to enter magnetite. The content of these elements is directly related to temperature in both magmatic magnetite and hydrothermal magnetite, so the formation temperature is an important indicator of the change in composition of magmatic and hydrothermal magnetite. The $(\mathrm{Al}+\mathrm{Mn})-(\mathrm{Ti}+\mathrm{V})$ diagram can be used to determine the formation temperature of magnetite [75,77]. The Ti content of Mag-II-A and Mag-II-B is very stable, between 753 and 1073 ppm and 4036 and $4281 \mathrm{ppm}$, respectively, indicating that their mineralization temperatures are relatively concentrated. We collected the Ti content data of magnetite from other types of deposits (shown in Table 6) and added them to the $(\mathrm{Al}+\mathrm{Mn})-(\mathrm{Ti}+\mathrm{V})$ diagram (Figure 7). It can be seen that the typical magmatic origin magnetite mineralization temperature falls within the range of $300-500{ }^{\circ} \mathrm{C}$ and $>500{ }^{\circ} \mathrm{C}$; the mineralization temperature Mag-II-A, Mag-II-B and IOCG-type magnetite and other hydrothermal origin magnetite falls within the range of $300-500^{\circ} \mathrm{C}$; and the mineralization temperature of metamorphic magnetite falls within the range of $200-300^{\circ} \mathrm{C}$. This feature implies the hydrothermal origin of the two. At the same time, the higher Ti content of Mag-II-B compared to Mag-II-A indicates that the formation temperature of the former is slightly higher than that of the latter, and the formation time is earlier.

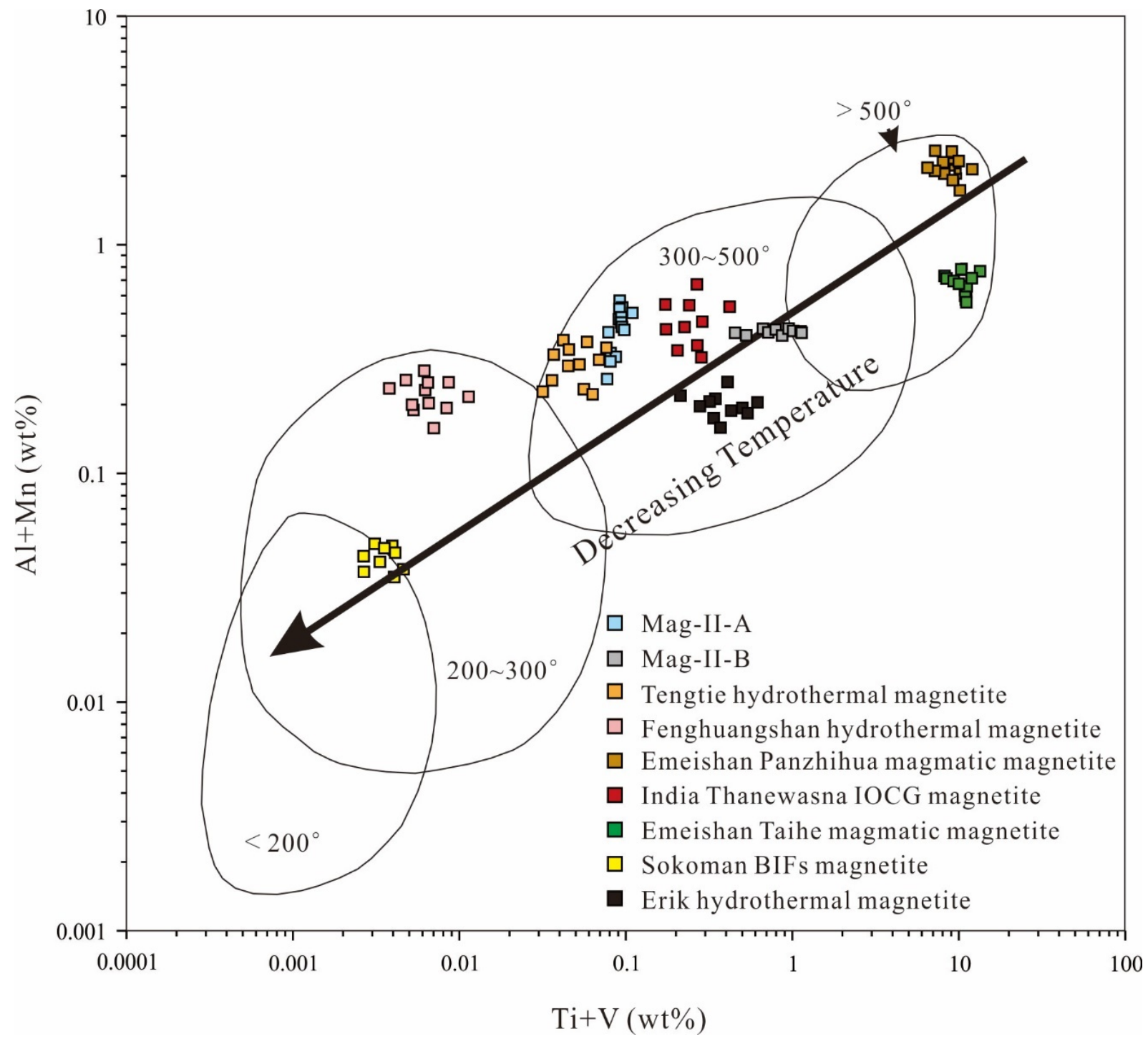

Figure 7. Magnetite $(\mathrm{Al}+\mathrm{Mn})-(\mathrm{Ti}+\mathrm{V})$ formation temperature diagram (modified after Nadoll et al. [75]). 
Table 6. Trace element contents of magnetite in different types of deposits.

\begin{tabular}{|c|c|c|c|c|c|c|c|c|c|c|c|c|c|}
\hline \multirow{2}{*}{ Deposit Type } & \multirow{2}{*}{ Typical Deposit } & \multirow{2}{*}{$\begin{array}{l}\text { Analysis } \\
\text { Method }\end{array}$} & \multicolumn{10}{|c|}{ Average Element Content (ppm) } & \multirow{2}{*}{ References } \\
\hline & & & $\mathrm{Mg}$ & Al & Mn & $\mathrm{Ti}$ & $\mathrm{Ca}$ & V & $\mathrm{Cr}$ & Co & $\mathrm{Ni}$ & $\mathrm{Zn}$ & \\
\hline \multirow{2}{*}{ Magmatic } & Emeishan Taihe deposit & LA-ICP-MS & 7109 & 3617 & 3277 & 107,520 & 337.7 & 3758 & 23 & 22.5 & 80 & 205.5 & \multirow{2}{*}{ Liu et al. [78] } \\
\hline & Emeishan Panzhihua deposit & LA-ICP-MS & 21,587 & 18,565 & 3218 & 85,668 & 62.9 & 3808 & 524.8 & 165.9 & 86.3 & 439.9 & \\
\hline \multirow{2}{*}{ Skarn } & Fenghuangshan $\mathrm{Cu}-\mathrm{Fe}-\mathrm{Au}$ deposit & LA-ICP-MS & 760.6 & 1957 & 1713 & 432.4 & 2588 & 22.5 & - & 58.8 & - & 150.4 & Huang et al. [79] \\
\hline & Tengtie skarn Fe deposit & LA-ICP-MS & 77.2 & 1402 & 2057 & 587.2 & 173.3 & 59.7 & 31.1 & 88.5 & 27.3 & 1439 & Zhao et al. [80] \\
\hline VMS & Erik Fe deposit & LA-ICP-MS & 203.7 & 865.5 & 1019 & 632.2 & 143.4 & 3527 & 6.5 & 4.2 & 54.1 & 103.9 & Ding et al. [81] \\
\hline \multirow[t]{2}{*}{$\mathrm{BIF}$} & Canada Sokoman Fe deposit & LA-ICP-MS & 138 & 162 & 390 & 19 & 73 & 26 & 6.6 & 6.5 & 1.5 & 7.7 & Chung et al. [82] \\
\hline & Thanewasna $\mathrm{Cu}-(\mathrm{Au})$ deposit & LA-ICP-MS & 180.8 & 816.7 & 2543 & 341.7 & 958.3 & 25,337 & 1382 & 895.1 & 3548 & 839.3 & Dora et al. [24] \\
\hline \multirow[t]{2}{*}{ IOCG } & Weizigou deposit Mag-II-A & LA-ICP-MS & 225.3 & 4146 & 210.8 & 885.5 & 226.5 & 18 & 148.8 & 11.6 & 23.5 & 137.8 & \\
\hline & Weizigou deposit Mag-II-B & LA-ICP-MS & 299 & 8299 & 1093 & 4166 & 51.1 & 84.7 & 15.5 & 13.1 & 1.5 & 314 & \\
\hline
\end{tabular}


Second, the oxygen fugacity has a significant effect on magnetite composition [83-85]. Toplis and Corgne [86] determined that under the same magma conditions, as the oxygen fugacity decreases, the $\mathrm{V}_{2} \mathrm{O}_{3}$ content in magnetite increases. Additionally, divalent cations such as $\mathrm{Ca}, \mathrm{Co}, \mathrm{Ni}, \mathrm{Mn}$ and $\mathrm{Mg}$ have no systemic dependence on oxygen fugacity, meaning that the content of $\mathrm{V}$ is closely related to the oxygen fugacity $\left(\mathrm{f}_{\mathrm{O} 2}\right)$. $\mathrm{V}$ ion substitution generally occurs under low oxygen fugacity conditions. Normally, $\mathrm{V}$ mainly exists in magnetite as $\mathrm{V}^{3+}$, with only a small amount of $\mathrm{V}^{4+}$ present, and it is difficult for $\mathrm{V}$ to enter magnetite under high oxygen fugacity conditions. Dare et al. [62] studied the Bushveld laminated Fe-Ti-V deposit and found that magnetite with a higher $\mathrm{V}$ content generally crystallized in the early stage, with a lower oxygen fugacity in the early stage, meaning that conditions were favorable for $\mathrm{V}$ to enter the magnetite, while the magnetite formed in the late stage of magmatic differentiation had a higher oxygen fugacity and was generally poor in V. The V content of Mag-II-A and Mag-II-B (16.1-21.4 ppm and 80.5-95.7 ppm, respectively) is two orders of magnitude different from that of typical magmatic magnetite such as Emeishan Taihe iron ore magnetite (3465-4250 ppm). However, it is not much different from the hydrothermal origin of IOCG-type deposits such as the magnetite (190-283 ppm) of the Laoshankou Fe-Cu-Au deposit in Xinjiang, which also indicates its hydrothermal origin. The slightly higher V content of Mag-II-B compared to Mag-II-A also indicates that its formation time is earlier.

At the same time, elements such as $\mathrm{Mg}, \mathrm{Ti}, \mathrm{V}, \mathrm{Cr}, \mathrm{Ni}$ and $\mathrm{Zn}$ can be used to distinguish the genesis of magnetite from magma and hydrothermal fluid [75]. The Ti content of most hydrothermal magnetite is less than 20,000 ppm, while the Al content is less than 10,000 ppm [87]. Compared with typical magmatic magnetite, Mg-II-A and Mag-II-B (hereinafter referred to as Mag-II together) have a relatively low $\mathrm{Ti}$ and $\mathrm{Al}$ content (average $\mathrm{Ti}$ content is $2197 \mathrm{ppm}$, average Al content is $5804 \mathrm{ppm}$ ), which indicates that Mg-II may be of hydrothermal origin. In the Fe-V/Ti diagram, Mag-II falls in the hydrothermal magnetite area (Figure 8a). The Ga-V diagram further proves that Mag-II should be a low-temperature hydrothermal magnetite $\left(<500{ }^{\circ} \mathrm{C}\right.$, [63], Figure $\left.8 \mathrm{~b}\right)$. The characteristics of the concentration of $\mathrm{Mg}$ and $\mathrm{Zn}$ can also determine the genesis of magnetite. In the hydrothermal environment, $\mathrm{Zn}$ is preferentially distributed in magnetite at low temperatures [88], and the concentration of $\mathrm{Mg}$ will also have a wide range (usually <2300 ppm, [64]). Mag-II has a relatively high $\mathrm{Zn}$ concentration (9.0-474.0 ppm) and a wide range of $\mathrm{Mg}$ concentrations (64.3-552.3 ppm), which further proves that it has a hydrothermal origin.
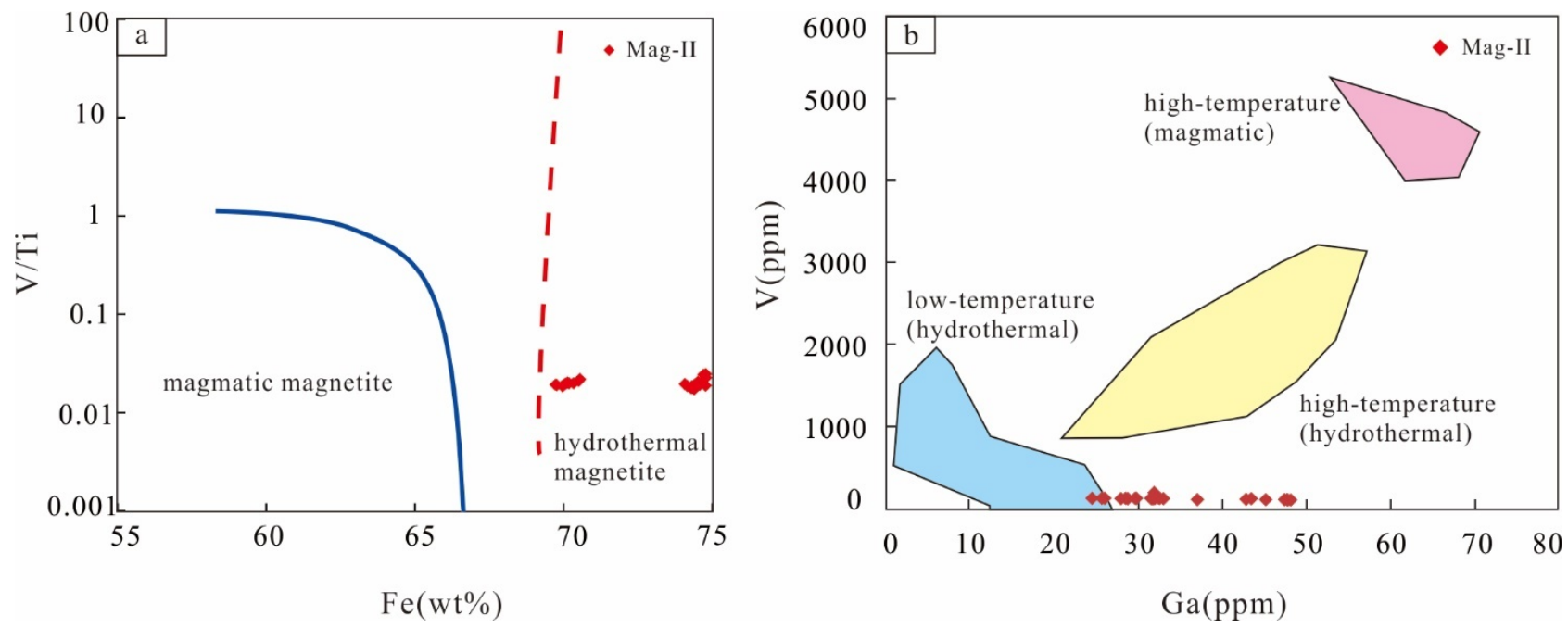

Figure 8. (a) Fe (wt \%) vs. V/Ti discrimination diagram for magnetite proposed by Wen et al. [89]; (b) V vs. Ga content in magnetite and data for high-temperature magmatic, high-temperature hydrothermal and low-temperature hydrothermal magnetite collected by Salazar et al. [90]. 


\subsection{Pyrite and Pyrrhotite Genetic Type and S-Pb Sources}

Sulfides (such as pyrite, pyrrhotite and chalcopyrite) are common minerals found in various deposits. More and more studies have shown that sulfides formed in different periods and under different conditions often contain information on the genesis of multiple periods, multiple stages and multiple generations. Their complex internal structure, morphological characteristics and multi-stage growth phenomena often correspond to the distribution and composition of their trace elements, especially elements that enter the crystal lattice of the main mineral in the form of a solid solution. The amounts of elements they replace are restricted by certain geological, physical and chemical conditions [16-18,20,22,90-95]. In addition, the S-Pb isotopic composition of sulfide plays an important role in constraining the source of metals [96-98].

$\mathrm{Co}$ and $\mathrm{Ni}$ are the most common trace elements found in pyrite. Many authors use $\mathrm{Co} / \mathrm{Ni}$ in pyrite as an indicator of the formation environment [16,99-101]. The changes in $\mathrm{Co}$ and $\mathrm{Ni}$ content are mainly controlled by the physical and chemical conditions present when the pyrite is formed. Therefore, pyrites of different genetic types usually have different $\mathrm{Co} / \mathrm{Ni}$ ratios $[20,82,93-95]$. For example, the Co/Ni ratio of magmatic pyrite is usually less than 1 , the $\mathrm{Co} / \mathrm{Ni}$ ratio of volcanic pyrite is usually between 5 and 100, and the $\mathrm{Co} / \mathrm{Ni}$ ratio of hydrothermal pyrite varies widely, but is generally greater than 1 . The content of $\mathrm{Co}$ and $\mathrm{Ni}$ in pyrrhotite also has certain characteristics, and it can be used as a composition standard to distinguish the genesis of the deposit [102]. For example, the pyrrhotite in a copper-nickel sulfide deposit is rich in $\mathrm{Ni}$ and poor in $\mathrm{Co}$, while the pyrrhotite in the magmatic hydrothermal deposit is rich in $\mathrm{Co}$ and poor in $\mathrm{Ni}$.

The Co and Ni contents of Py-II vary widely, but the Co/Ni ratio of Py-II is between 2.6 and 5.6, with an average value of 3.8, both greater than 1. Py-III has a relatively concentrated $\mathrm{Co}$ and $\mathrm{Ni}$ content, and its $\mathrm{Co} / \mathrm{Ni}$ comparison is also relatively uniform, ranging from 3.0 to 5.1. The $\mathrm{Co}$ and $\mathrm{Ni}$ content of Po is relatively uniform, and its $\mathrm{Co} / \mathrm{Ni}$ ratio is between 2.0 and 3.5, both greater than 1 . All of these fall into the hydrothermal area of the Co-Ni covariance diagram (Figure 9a), indicating that their genesis is related to magmatic hydrothermal fluid.
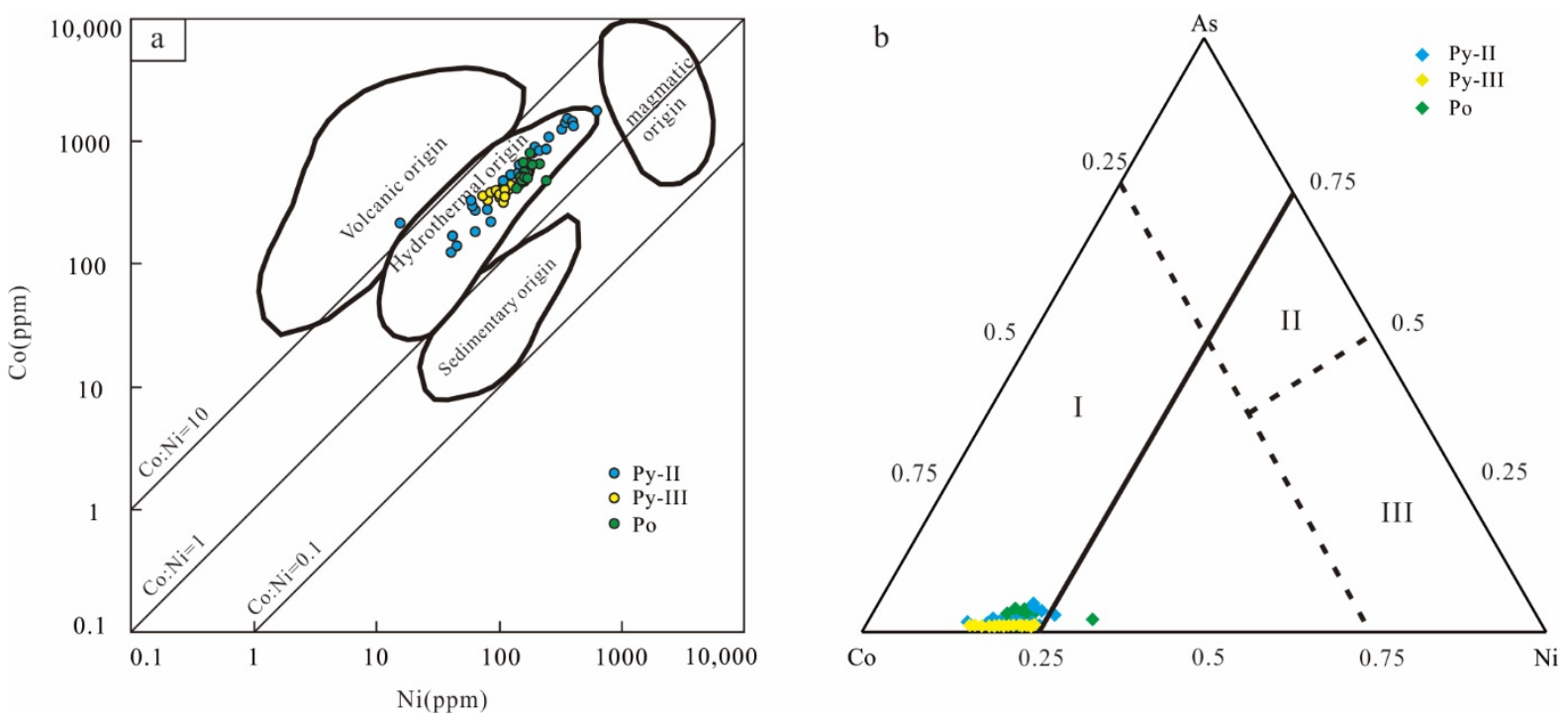

Figure 9. (a) Co-Ni discriminant diagram (after Bralia et al. [100]); (b) Co-Ni-As discriminant diagram (I-magmatic hydrothermal type; II-Carlin type; III-metamorphic hydrothermal type, after Yan et al. [93]).

The Co-Ni-As system of pyrite and pyrrhotite is also indicative of the genesis of ore deposits. The content changes in gold deposits of different genetic types are closely related to their respective geological effects $[93,103]$. The As in pyrite can replace $S$ through isomorphism, and As as a low-temperature element tends to be enriched at low temperatures. 
In magmatic hydrothermal gold mines, the source of hydrothermal fluid is a mixture of magmatic water and atmospheric water, and the content of As depends on the ratio of atmospheric water to magmatic water. The larger the ratio is, the closer the point to the As vertex area in the Co-Ni-As discriminant chart is (Figure 9b). Py-II, Py-III and Po fall into the magma hydrothermal area in the $\mathrm{Co}-\mathrm{Ni}$-As discriminant chart, which is close to the Co apex area. This indicates that the As content of Py-II, Py-III and Po in the Weizigou deposit is relatively low, and the atmospheric water in the hydrothermal fluid accounts for a relatively small proportion.

The $\delta^{34} S$ values of coexisting fluids can be calculated from the $\delta^{34} S$ values of sulfides. Previous studies have shown that the origin of sulfur in ore deposits can be thought of in terms of the calculated isotopic composition of total sulfur in the hydrothermal solution $\left(\delta^{34} S_{\Sigma S}\right)$ [104]. In the Weizigou deposit, sulfide minerals include pyrite, chalcopyrite and pyrrhotite, with no trace of sulfates, indicating relatively low $-\mathrm{f}_{\mathrm{O} 2}$ conditions [96]. Therefore, the $\delta^{34} S$ values of sulfide minerals could represent bulk-fluid values [96]. There are three major sulfur reservoirs on Earth that have uniform sulfur isotopic compositions: (1) mantle or magmatic ( $0 \pm 3 \%$, [104]); (2) seawater (20\%), in which sulfur is present as $\mathrm{SO}^{2-}$ [98]; (3) reduced (depositional) sulfur or biogenic sulfur, which are characterized by negative $\delta^{34} \mathrm{~S}$ values [105]. The $\delta^{34} \mathrm{~S}$ values from sulfides display a relatively narrow range from $4.70 \%$ to $12.89 \%$ (Figure 10$)$, with an average of $11.55 \%$ o $(n=28)$, which is higher than the range in magmatic fluids and lower than the range in seawater. The narrow range of sulfur isotopic data is likely a single source. In hydrothermal deposits, such isotopic features are usually attributed to fluids related to evaporate [2]. However, no evaporate has been discovered in the orefield before. The $\delta^{34} \mathrm{~S}$ values of granitic gneiss and meta-gabbro in the orefield range from $7.44 \%$ to $8.44 \%$ (avg. $7.96 \%$ ) and $4.37 \%$ o to $10.54 \%$ (avg. $6.55 \%$ ), which are slightly lower than the values found in sulfides. Therefore, the $\delta^{34} \mathrm{~S}$ values of sulfides may be due to the interaction of magmatic fluids and seawater.

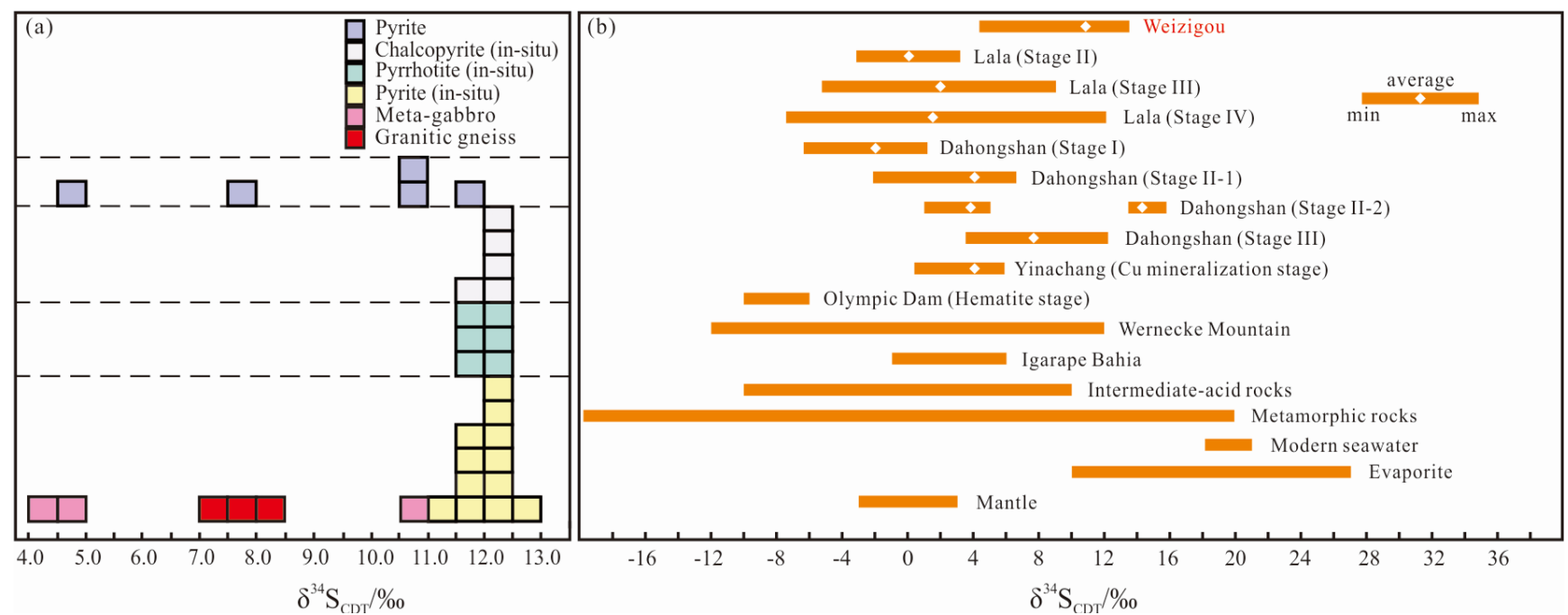

Figure 10. (a) Sulfur isotopic compositions of sulfide from the Weizigou deposit. (b) Comparison of Sulfur isotope values in different regions.

The $\mathrm{Pb}$ isotopic compositions of sulfides reflect the sources of ore-forming minerals and initial $\mathrm{Pb}$ isotopic compositions [97]. We can use ${ }^{207} \mathrm{~Pb} /{ }^{204} \mathrm{~Pb}-{ }^{206} \mathrm{~Pb} /{ }^{204} \mathrm{~Pb}$ and ${ }^{208} \mathrm{~Pb} /{ }^{204} \mathrm{~Pb}-{ }^{206} \mathrm{~Pb} /{ }^{204} \mathrm{~Pb}$ diagrams to observe and analyze mineral distribution characteristics and correlations, in order to make conclusions concerning the sources of ore-forming metals. Stacey et al. [106] summarized that, in the tectonic discriminant diagram, if samples are located above the evolution line of the orogeny, lead is contained in the upper crust component; a location near the evolution line indicates that the lead has a mixed character and a location below the evolution line indicates that the lead was derived 
from the mantle or the lower crust. Sulfide lead isotopic compositions for the Weizigou deposit have values of ${ }^{206} \mathrm{~Pb} /{ }^{204} \mathrm{~Pb}=18.605-20.136,{ }^{207} \mathrm{~Pb} /{ }^{204} \mathrm{~Pb}=15.637-15.710$ and ${ }^{208} \mathrm{~Pb} /{ }^{204} \mathrm{~Pb}=38.534-39.129$, plotted near the orogenic belt and close to the upper crust on the ${ }^{207} \mathrm{~Pb} /{ }^{204} \mathrm{~Pb}$ vs. ${ }^{206} \mathrm{~Pb} /{ }^{204} \mathrm{~Pb}$ and ${ }^{208} \mathrm{~Pb} /{ }^{204} \mathrm{~Pb}$ vs. ${ }^{206} \mathrm{~Pb} /{ }^{204} \mathrm{~Pb}$ diagrams (Figure 11), indicating that the lead was derived from a mixed source.
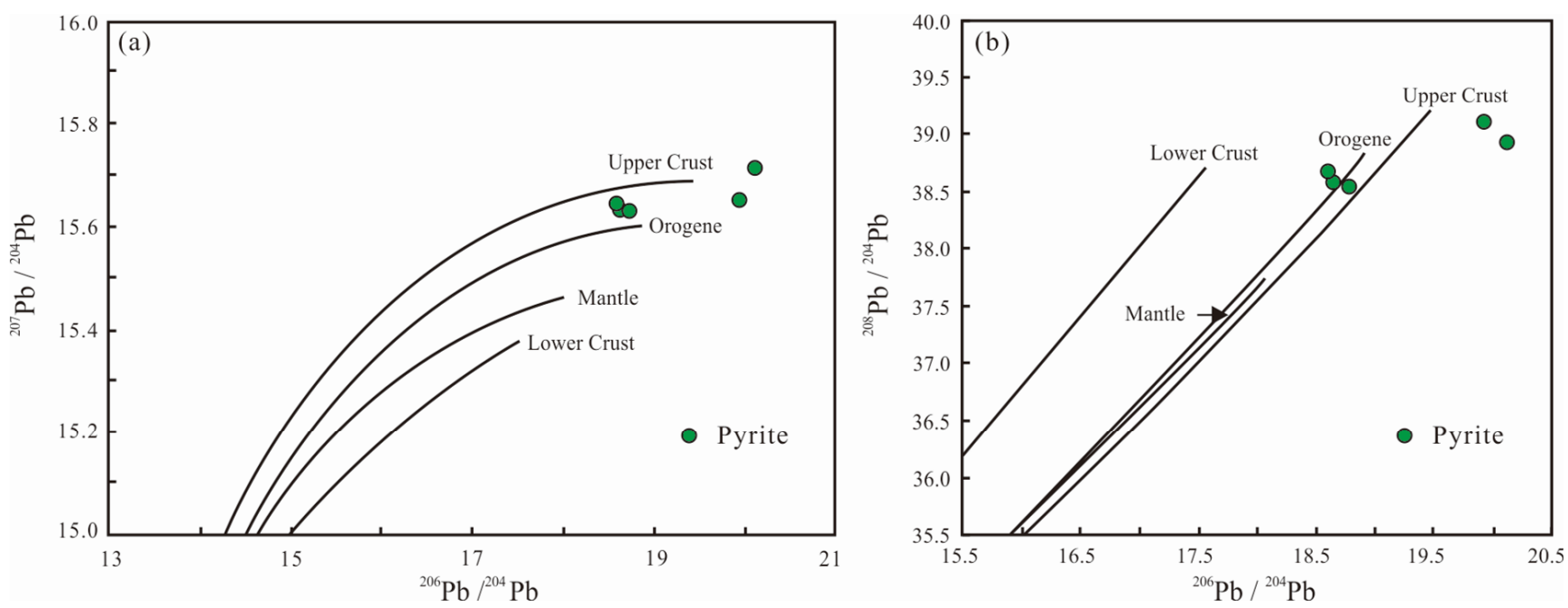

Figure 11. Lead isotopic compositions of pyrite from the Weizigou deposit (modified after Zartman and Doe, [107]). (a) ${ }^{206} \mathrm{~Pb} /{ }^{204} \mathrm{~Pb}-{ }^{207} \mathrm{~Pb} /{ }^{204} \mathrm{~Pb}$; (b) ${ }^{206} \mathrm{~Pb} /{ }^{204} \mathrm{~Pb}-{ }^{208} \mathrm{~Pb} /{ }^{204} \mathrm{~Pb}$.

\subsection{Ore Deposit Mineralization Age and Genetic Type}

Previous studies have supposed that the gold orebodies in this area are associated with the widely exposed migmatitic granite. No intrusions have been discovered in the orefield, and gold mineralization has a close relationship with magnetite-pyrrhotite-chalcopyrite. Therefore, the crystallization age of migmatitic granite can represent the ore-forming age $(481 \pm 10 \mathrm{Ma})$ [28]. However, based on our field research, the gold orebodies in this area are associated with amphibolite and magnetite (Figure $2 \mathrm{~b}$ ), which are crosscut by later sulfides. The part in which iron grade is high is also enriched in gold. Thus, we suppose that the $\mathrm{Au}-\mathrm{Fe}$ mineralization as well as the later $\mathrm{Cu}$ mineralization are due to different metallogenic events.

Pyrite Re-Os dating can be used to determine the metallogenic age of a deposit; however, the margin of error and MSWD of pyrite isochron ages can be larger than $\pm 10 \mathrm{Ma}$ (maximum $\pm 148 \mathrm{Ma}$ ) and $10 \mathrm{Ma}$ (maximum $184 \mathrm{Ma}$ ), respectively [108]. This is caused by the low Re and Os contents in pyrite and pyrite contamination $[108,109]$. For the Weizigou deposit, the Re and Os contents in pyrite are low and close to the detection limit, thus increasing the error of the calculated isochron age [110]. The isochron age of $196 \pm 110 \mathrm{Ma}$ (MSWD = 13,608; Figure 5a) obtained from eight pyrite samples is similar to the isochron age of $197 \pm 11 \mathrm{Ma}$ (MSWD = 50; Figure 5b) obtained from four pyrite samples. Given that the latter isochron age has a smaller MSWD and a higher reliability, it might be able to, more accurately, represent the timing of the matallogenic event. Therefore, the sulfides (pyrite, pyrrhotite and chalcopyrite) may have formed in the Early Jurassic. Additionally, the meta-gabbro from the Weizigou deposit yielded two age peaks of $292 \mathrm{Ma}$ and 271-259 Ma, representing the crystallization and metamorphic ages, respectively. Therefore, based on field observation and mineral paragenesis, we consider that all gold orebodies are associated with magnetite formed in the metamorphic hydrothermal stage in the MiddleLate Permian, earlier than later sulfides such as pyrite, pyrrhotite and chalcopyrite in the magmatic hydrothermal stage.

When considering the genetic type of the deposit, we found that the surrounding rocks of the ore body are granitic gneiss and meta-gabbro and that there are no carbonate rocks or typical skarn minerals, so the possibility that the deposit is skarn-type mineralization 
can be ruled out. The ore bodies occur in meta-gabbro in the veined form and no hematite or replacement of clastic sulfides can be seen, which does not support the halmyrolysis model [111], so BIF and VMS-type mineralization can be excluded. The in situ LA-ICP-MS test results also show that the content of Ti and V in Mag-II is two to three orders of magnitude different from that of magnetite in magmatic deposits. This shows that the Weizigou deposit is also not related to the magmatic deposit.

When we compare the Weizigou deposit with the IOCG-type deposit, we can find that it has some characteristics of IOCG-type mineralization. For example: (1) Veined IOCGtype orebodies mainly formed within the intrusions, notably equigranular gabbro and diorite [1]. The residual minerals and textures in the meta-gabbro imply that the original rock was gabbro; (2) All orebodies produced in the meta-gabbro were, mainly developed from potassic alteration including biotite, sericite and minor sodic alteration with apatite, albite, and chlorite, similar to the alteration characteristics of IOCG deposits [1,12]; (3) A large amount of low-Ti magnetite was developed. We use the $\mathrm{Ti}+\mathrm{V}-\mathrm{Ca}+\mathrm{Al}+\mathrm{Mn}$ diagram (Figure 12a) to determine the genesis of Mag-II deposits. In this diagram, MagII falls within the area of skarn-type deposits, IOCG-type deposits, and porphyry-type deposits. In addition, the $\mathrm{Cr}$ and $\mathrm{V}$ concentrations of magnetite can be used to distinguish IOCG from other deposit types-that is, magnetite with $\mathrm{Cr}<1000 \mathrm{ppm}$ and $\mathrm{V}<300 \mathrm{ppm}$ is usually associated with IOCG deposits [112]. The low V concentration is caused by the crystallization of magnetite at a relatively low temperature. The Mag-II in the Weizigou deposit contains similar $\mathrm{V}$ and $\mathrm{Cr}$ concentrations to the IOCG-type magnetite, and falls into the area close to the IOCG-type deposit in the V-Cr diagram (Figure 12b). In these two diagrams, the magnetite sample points do not fall in the relatively close area, because the formation time of Mag-II-B was earlier than that of Mag-II-A, and the mineralization temperature and oxygen fugacity were relatively high, resulting in only a small difference in the Ti and $\mathrm{V}$ contents $[75,77]$.
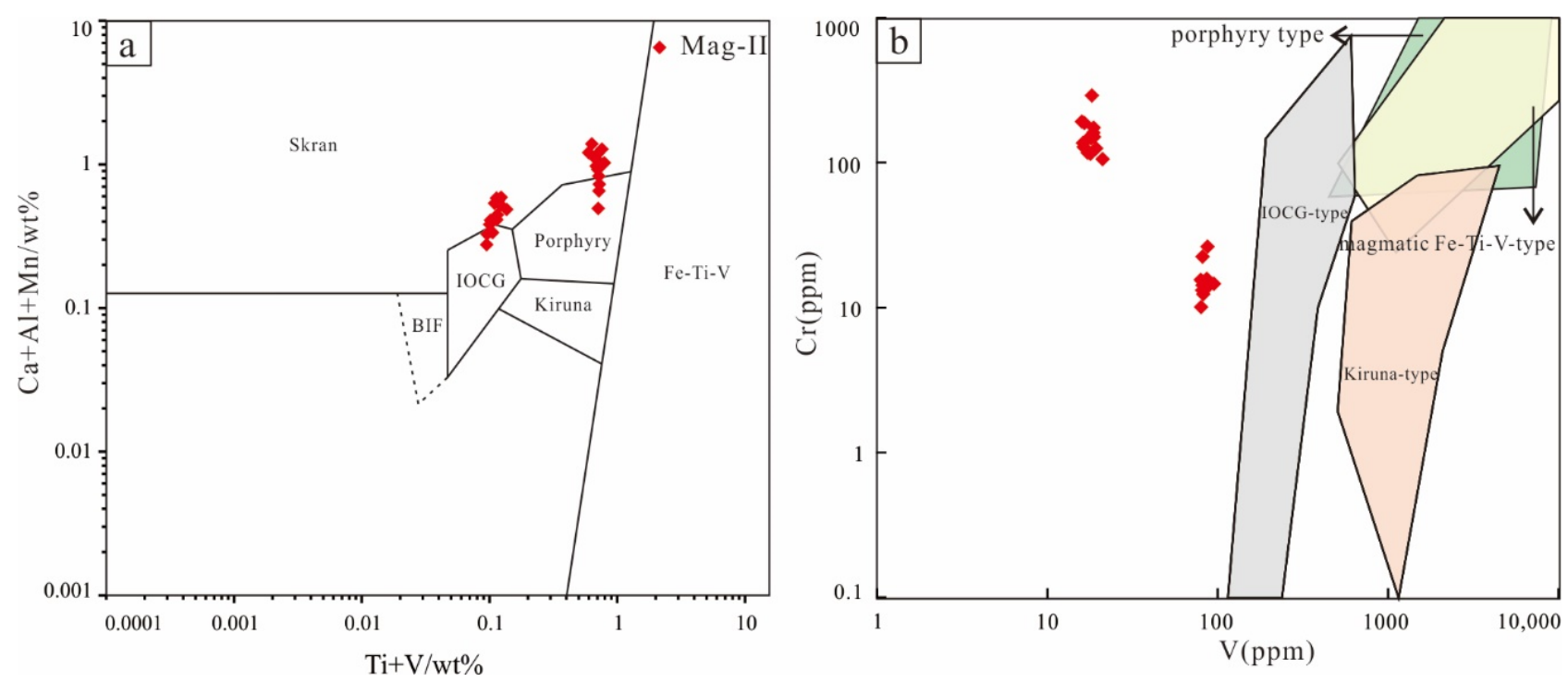

Figure 12. (a) $\mathrm{Ti}+\mathrm{V}$ vs. $\mathrm{Ca}+\mathrm{Al}+\mathrm{Mn}$ (wt. \%) discriminant diagrams (modified from Dupuis and Beaudoin. [67]); (b) Cr vs. V diagram for magnetite to distinguish different deposit types (modified after Knipping et al. [112] with typical IOCG magnetite compositions from Carew [65] and Dare et al. [63]).

To sum up our findings, we propose the genetic model of the Weizigou deposit to be follows: In the Late Carboniferous, as the Paleo-Asian Ocean continued to subduct into the Jiamusi massif, intermediate-basic magma enriched in Fe ascended into the shallow crust and intruded into the granitic gneiss. Due to the decrease in pressure and the rapid decrease in temperature, crystallization differentiation resulted in the formation of gabbro. The hydrothermal fluids in the late magma phase extracted and metasomatized the previously 
formed gabbro, which led to the initial precipitation of Fe and a small amount of euhedral magnetite (Figure 13a).
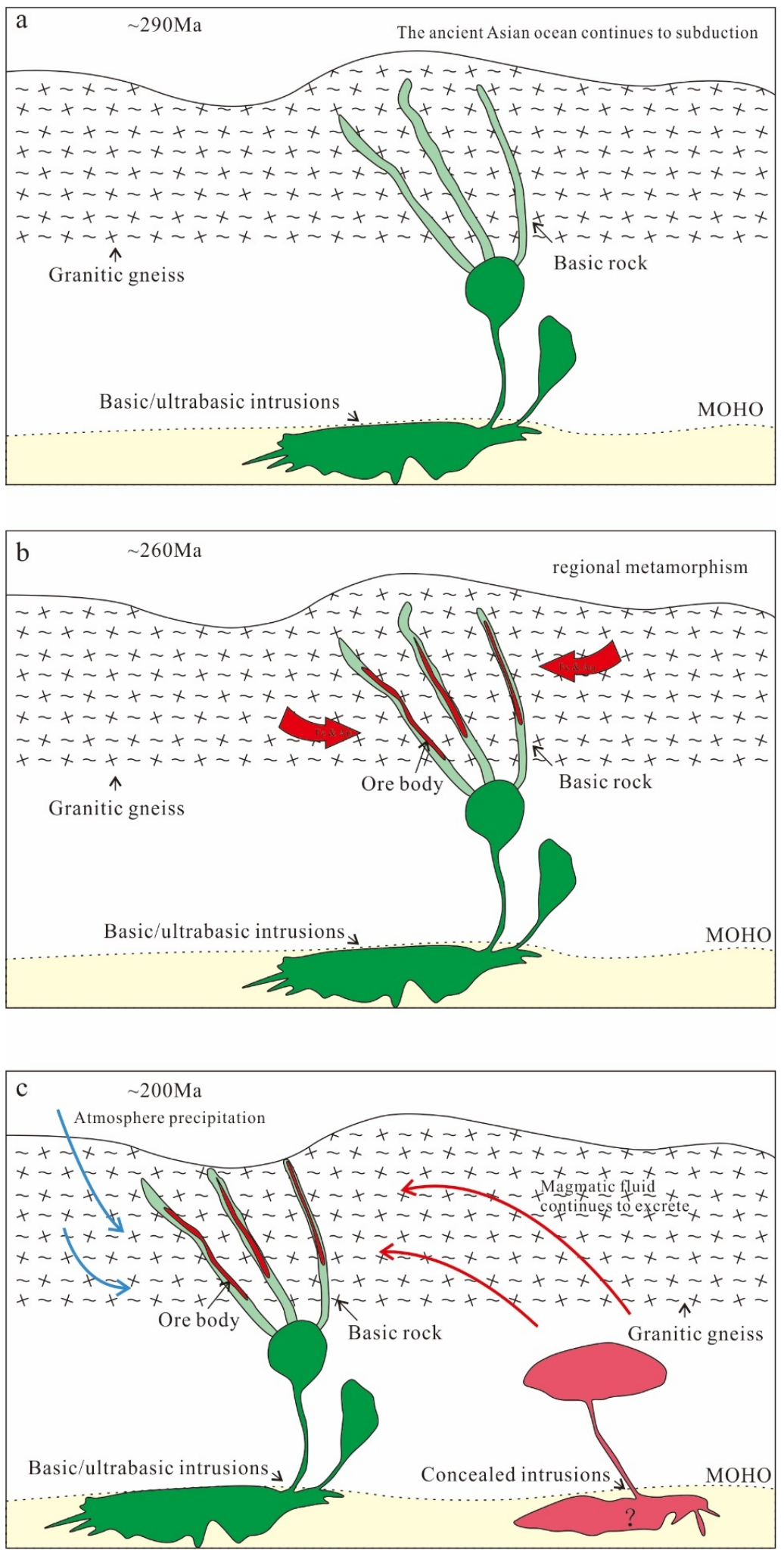

Figure 13. Metallogenic model diagram of the Weizigou deposit. (a) intermediate-basic magma ascended into the shallow crust and intruded into the granitic gneiss; (b) metamorphic fluid extracted Fe and $\mathrm{Au}$ and generat orebodies; (c) magmatic-hydrothermal mineralization in the Early Jurassic. $\mathrm{MOHO}-$ Mohorovicic Discontinuity. 
The closure of the Paleo-Asian Ocean resulted in regional medium-low grade metamorphism occurring in the Late Permian, which generated the meta-gabbro. Later, metamorphic fluid eluviated and extracted Fe and $\mathrm{Au}$ from the meta-gabbro, generating abundant magnetite and Fe-Au orebodies. (Figure 13b).

Finally, in the Early Jurassic, magmatic fluid from the deep rock mass precipitated in the fractures, forming later sulfides (Figure 13c). In conclusion, two-phase mineralization namely IOCG-type mineralization in the Late Permian and magmatic-hydrothermal mineralization in the Early Jurassic can be identified in the Weizigou gold deposit.

\section{Conclusions}

1. There are four ore bodies in the Weizigou deposit, all of which are vein-like closely co-existing with meta-gabbro. The mineralization of gold and iron only develops in meta-gabbro. Wall rock alteration is developed, mainly chlorite, epidote and biotite. The main metal minerals developed in the deposit include magnetite, pyrite, pyrrhotite and chalcopyrite.

2. Four pyrite samples yielded a Re-Os icochron age of $197 \pm 11$ Ma and Osi values are similar to that of the lower crust.

3. Sulfur maybe derived from the granitic gneiss and meta-gabbro exposed in the orefield and lead has a mixed source. Carbon mainly derived from the granitic gneiss.

4. The in situ LA-ICP-MS trace element analysis results show that the formation of magnetite is closely related to IOCG-type mineralization, and the formation of pyrite and pyrrhotite is related to magmatic hydrothermal fluid.

5. The Weizigou Au deposit experienced two-period mineralization, namely the IOCGtype mineralization in the Late Permian and the magmatic hydrothermal mineralization in the Early Jurassic.

Author Contributions: Conceptualization, Y.G. and Y.H.; formal analysis, Y.G.; investigation, Y.G., Y.H. and S.L.; methodology, Y.G. and Y.H.; supervision, Y.H.; writing-original draft, Y.G. All authors have read and agreed to the published version of the manuscript.

Funding: This work is financially supported by the National Natural Science Foundation of China (NSFC), Grant/Award Number: 41802078.

Acknowledgments: We are grateful to reviewers for their constructive comments and significant help in improving the document and those personnel assisting in field campaigns and laboratories.

Conflicts of Interest: The authors declare no conflict of interest.

\section{References}

1. Mao, J.W.; Yu, J.J.; Yuan, S.D.; Cheng, Y.B.; Xie, G.Q.; Hou, K.J.; Xiang, J.F.; Yang, Z.X. Iron oxide-copper-gold deposits: Characteristics, present research situation and ore prospecting. Miner. Depos. 2008, 6, 267-278. (In Chinese)

2. Zhao, X.F.; Zhou, M.F. Fe-Cu deposits in the Kangdian region, SW China: A Proterozoic IOCG (iron-oxide-copper-gold) metallogenic province. Miner. Depos. 2011, 46, 731-747. [CrossRef]

3. Chen, W.; Zhao, X.F.; Li, X.C.; Zhou, M.F. An overview on the characteristics and origin of iron-oxide copper gold (IOCG) deposits in China. Acta Petrol. Sin. 2019, 35, 99-118. (In Chinese)

4. Roberts, D.E.; Hudson, G.R.T. The Olympic Dam copper-uranium-gold deposit, Roxby Downs, South Australia. Econ. Geol. 1983, 78, 799-822. [CrossRef]

5. Hitzman, M.W.; Oreskes, N.; Einaudi, M.T. Geological characteristics and tectonic setting of proterozoic iron oxide (Cu-U-Au-REE) deposits. Precambrian Res. 1992, 58, 241-287. [CrossRef]

6. Sillitoe, R.H. Iron oxide-copper-gold deposits: An Andean view. Miner. Depos. 2003, 38, 787-812. [CrossRef]

7. Zhang, X.C. The characteristics of the overseas iron-oxide $\mathrm{Cu}-\mathrm{Au}$ deposits and the present situation of the studies. Adv. Earth Sci. 2003, 18, 551-560. (In Chinese)

8. Oliver, N.H.S.; Cleverley, J.S.; Mark, G.; Pollard, P.J.; Fu, B.; Marshall, L.J.; Rubenach, M.J.; Williams, P.J.; Baker, T. Modeling the role of sodic alteration in the genesis of iron oxide-copper-gold deposits, Eastern Mount Isa block, Australia. Econ. Geol. 2004, 99, 1145-1176. [CrossRef]

9. Williams, P.J.; Barton, M.; Johnson, D.A.; Fontboté, L.; de Haller, A.; Mark, G.; Oliver, N.H.S.; Marschik, R. Iron oxide copper-gold deposits: Geology, space-time distribution, and possible modes of origin. Econ. Geol. 2005, 100, 371-405. 
10. Pollard, P.J. An intrusion-related origin for $\mathrm{Cu}$-Au mineralization in iron oxide-copper-gold (IOCG) provinces. Miner. Depos. 2006, 41, 179-187. [CrossRef]

11. Nie, F.J.; Jiang, S.H.; Lu, Y.M. Geological features, ore-forming processes and prospecting model of iron oxide-copper-gold deposits. Geol. China 2008, 35, 1074-1087. (In Chinese)

12. Groves, D.I.; Bierlein, F.P.; Meinert, L.D.; Hitzman, M.W. Iron Oxide Copper-Gold (IOCG) Deposits through Earth History: Implications for Origin, Lithospheric Setting, and Distinction from Other Epigenetic Iron Oxide Deposits. Econ. Geol. 2010, 105, 641-654. [CrossRef]

13. Chen, H.Y. Externa sulphur in IOCG mineralization: Implications on difinition and classification of the IOCG clan. Ore Geol. Rev. 2013, 51, 74-78. [CrossRef]

14. Zhao, X.F.; Zhou, M.F.; Su, Z.K.; Li, X.C.; Chen, W.T.; Li, J.W. Geology, Geochronology, and Geochemistry of the Dahongshan Fe-Cu-(Au-Ag) Deposit, Southwest China: Implications for the Formation of Iron Oxide Copper-Gold Deposits in Intracratonic Rift Settings. Econ. Geol. 2017, 112, 603-628. [CrossRef]

15. Large, R.R.; Maslennikon, W.; Robert, F.; Danyushevsky, L.V.; Chang, Z.S. Multistage sedimentary and metamorphic origin of pyrite and gold in the giant Sukhoi Log deposit, Lena gold province, Russia. Econ. Geol. 2007, 102, 1233-1267. [CrossRef]

16. Large, R.R.; Halpin, J.A.; Danyushevsky, L.V.; Maslennikov, V.V.; Bull, S.W.; Long, J.A.; Gregory, D.D.; Lounejev, E.; Lyons, T.W.; Sack, P.J. Trace element content of sedimentary pyrite as a new proxy for deep-time ocean-atmosphere evolution. Earth Planet. Sci. Lett. 2014, 389, 209-220. [CrossRef]

17. Deditius, A.P.; Reich, M.; Kesler, S.E.; Utsunomiya, S.; Chryssoulis, S.L.; Walshe, J.; Ewing, R.C. The coupled geochemistry of Au and as in pyrite from hydrothermal ore deposits. Geochem. Cosmochim. Acta 2014, 140, 644-670. [CrossRef]

18. Franchini, M.; Mcfarlane, C.; Maydagán, L.; Reich, M.; Lentz, D.R.; Meinert, L.; Bouhier, V. Trace metals in pyrite and marcasite from the Agua Rica porphyry-high sulfidation epithermal deposit, Catamarca, Argentina: Textural features and metal zoning at the porphyry to epithermal transition. Ore Geol. Rev. 2015, 66, 366-387. [CrossRef]

19. Ye, T.; Li, N. The In-situ LA-ICPMS analyses of minor and trace elements in pyrite and its implication in Au deposit. Chin. J. Geol. 2015, 50, 1178-1199. (In Chinese)

20. Belousov, I.; Large, R.R.; Meffre, S.; Danyushevsky, L.V.; Steadman, J.; Beardsmore, T. Pyrite compositions from VHMS and orogenic Au deposits in the Yilgarn Craton, Western Australia: Implications for gold and copper exploration. Ore Geol. Rev. 2016, 79, 474-499. [CrossRef]

21. Large, R.R.; Danyushevsky, L.; Hollit, C.; Maslennikov, V.; Meffre, S.; Gilbert, S.; Bull, S.; Scott, R.; Emsbo, P.; Thomas, H.; et al. Gold and trace element zonation in pyrite using a laser imaging technique: Implications for the timing of gold in Orogenic and Carlin-style sediment-hosted deposits. Econ. Geol. 2009, 104, 635-668. [CrossRef]

22. Reich, M.; Deditius, A.; Chryssoulis, S.; Li, J.W.; Ma, C.Q.; Parada, M.A.; Barra, F.; Mittermayr, F. Pyrite as a record of hydrothermal fluid evolution in a porphyry copper system: A SIMS/EMPA trace element study. Geochim. Cosmochim. Acta 2013, $104,42-62$. [CrossRef]

23. Chen, Y.H.; Lan, T.G.; Wang, H.; Tang, Y.W.; Dai, Z.H. LA-ICP-MS trace element characteristics of magnetite from the Zhangjiawa iron deposit, Laiwu and constraints on metallogenic processes. Earth Sci. Front. 2018, 25, 32-49.

24. Dora, M.L.; Upadhyay, D.; Randive, K.R.; Shareef, M.; Baswani, S.R.; Ranjan, S. Trace element geochemistry of magnetite and pyrite and sulfur isotope geochemistry of pyrite and barite from the Thanewasna $\mathrm{Cu}-(\mathrm{Au})$ deposit, western Bastar Craton, central India: Implication for ore genesis. Ore Geol. Rev. 2020, 117, 103262. [CrossRef]

25. Liang, P.; Wu, C.; Hu, X.; Xie, Y.L. Textures and geochemistry of magnetite: Indications for genesis of the Late Paleozoic Laoshankou Fe-Cu-Au deposit NW China. Ore Geol. Rev. 2020, 124, 103632. [CrossRef]

26. Zhang, Y.; Lian, Y.L.; Jin, E.M. Geological features and prospecting orientation of the Weizigou gold deposit in Heilongjiang Province. Geol. Resour. 2011, 20, 426-429. (In Chinese)

27. Cheng, J. Geological Characteristics and Prospecting Direction of the Weizigou Gold Deposit in the Jixi County, Heilongjiang. Master's Thesis, Jilin University, Changchun, China, 2013. (In Chinese).

28. Bo, J.W. Metallogenic characteristics and comprehensive information prediction of Fe and Au deposits in Jiantang area Heilongjiang Province. Master's Thesis, Jilin University, Changchun, China, 2016. (In Chinese).

29. Wang, F.; Xu, W.L.; Xu, Y.G.; Gao, F.H.; Ge, W.C. Late Triassic bimodal igneous rocks in eastern Heilongjiang Province, NE China: Implications for the initiation of subduction of the Paleo-Pacific Plate beneath Eurasia. J. Asian Earth Sci. 2015, 97, 406-423. [CrossRef]

30. Heilongjiang Bureau of Geology and Mineral Resources. Regional Geology of Heilongjiang Province; Geological Publishing House: Beijing, China, 1993; pp. 347-418. (In Chinese)

31. Bai, J.W.; Wang, W.X.; Zhang, H.R. Character of glaucophane schists in metamorphic zone in Yilan, Mudanjiang, Heilongjiang. Acta Petrol. Mineral. 1988, 7, 298-308. (In Chinese)

32. Wu, F.Y.; Yang, J.H.; Lo, C.H.; Wilde, S.A.; Sun, D.Y.; Jahn, B.M. The Heilongjiang Group: A Jurassic accretionary complex in the Jiamusi Massif at the western Pacific margin of northeastern China. Isl. Arc 2007, 16, 156-172. [CrossRef]

33. Zhou, J.B.; Pu, X.G.; Hou, H.S.; Han, W.; Cao, J.L.; Li, G.Y. The Mesozoic accretionary complex in NE China and its tectonic implications for the subduction of the Paleo-Pacific plate beneath the Eurasia. Acta Petrol. Sin. 2018, 34, $2845-2856$.

34. Li, W.M.; Liu, Y.J.; Zhao, Y.L.; Feng, Z.Q.; Zhou, J.P.; Wen, Q.B.; Liang, C.Y.; Zhang, D. Tectonic evolution of the Jiamusi Block, NE China. Acta Petrol. Sin. 2020, 36, 665-684. (In Chinese) 
35. Wu, F.Y.; Sun, D.Y.; Ge, W.C.; Zhang, Y.B.; Grant, M.L.; Wilde, S.A.; Jahn, B.M. Geochronology of the Phanerozoic granitoids in northeastern China. J. Asian Earth Sci. 2011, 41, 1-30. [CrossRef]

36. Jiang, J.S. Regional metamorphism and evolution of Mashan khondalite series. Acta Petrol. Mineral. 1992, 11, 97-100. (In Chinese)

37. Jiang, J.S. Geochemistry of Mashan-Group khondalite series. Geochemica 1993, 2, 363-372. (In Chinese)

38. Guo, X.Z.; Takasu, A.; Liu, Y.J.; Li, W.M. Zn-rich spinel in association with quartz in the Al-rich metapelites from the Mashan Khondalite series, NE China. J. Earth Sci. 2014, 25, 207-223. [CrossRef]

39. Li, W.M.; Takasu, A.; Liu, Y.J.; Genser, J.; Neubauer, F.; Guo, X.Z. ${ }^{40} \mathrm{Ar} /{ }^{39} \mathrm{Ar}$ ages of the high-P/T metamorphic rocks of the Heilongjiang Complex in the Jiamusi Massif, northeastern China. J. Mineral. Petrol. Sci. 2009, 104, 110-116. [CrossRef]

40. Li, W.M.; Takasu, A.; Liu, Y.J.; Genser, J.; Zhao, Y.L.; Han, G.; Guo, X.Z. U-Pb and ${ }^{40} \mathrm{Ar} /{ }^{39} \mathrm{Ar}$ age constrains on protolish and high-P/T type metamorphism of the Heilongjiang Complex in the Jiamusi Massif, NE China. J. Mineral. Petrol. Sci. 2010, 106, 326-331. [CrossRef]

41. Zhou, J.B.; Wilde, S.A.; Zhao, G.C.; Zhang, X.Z.; Zheng, C.Q.; Wang, Y.J.; Zhang, X.H. The onset of Pacific margin accretion in NE China: Evidence form the Heilongjiang high-pressure metamorphic belt. Tectonophysics 2009, 478, 230-246. [CrossRef]

42. Wang, C.W.; Jin, W.; Zhang, X.Z.; Ma, Z.H.; Chi, X.G.; Liu, Y.J.; Li, N. New understanding of the late Paleozoic tectonics in northeastern China and adjacent areas. J. Stratigr. 2008, 32, 119-136.

43. Ma, Y.P.; Ren, Y.S.; Hao, Y.J.; Lai, K.; Zhao, H.L.; Liu, J. Genesis and material source of scheelite of Yangbishan iron-tungsten deposit in Heilongjiang, NE China. J. Jilin Univ. Earth Sci. Ed. 2018, 48, 105-117. (In Chinese)

44. Sun, M.D. Late Mesozoic Magmatism and Its Tectonic Implication for the Jiamusi Block and Adjacent Areas of NE China. Ph.D. Thesis, Zhejiang University, Hangzhou, China, 2013. (In Chinese).

45. Sun, M.D.; Xu, Y.G.; Wilde, S.A.; Chen, H.L.; Yang, S.F. The Permian Dongfanghong island-arc gabbro of the Wandashan Orogen, NE China: Implications for Paleo-Pacific subduction. Tectonophysics 2015, 659, 122-136. [CrossRef]

46. Bi, J.H.; Ge, W.C.; Yang, H.; Zhao, G.C.; Yu, J.J.; Zhang, Y.L.; Wang, Z.H.; Tian, D.X. Petrogenesis and tectonic implications of Early Paleozoic granitic magmatism in the Jiamusi Massif, NE China: Geochronological, geochemical and Hf isotopic evidence. J. Asian Earth Sci. 2014, 96, 308-331. [CrossRef]

47. Yang, H.; Ge, W.C.; Zhao, G.C.; Yu, J.J.; Zhang, Y.L. Early Permian-Late Triassic granitic magmatism in the Jiamusi-Khanka Massif eastern segment of the Central Asian Orogenic Belt and its implications. Gondwana Res. 2015, 27, 1509-1533. [CrossRef]

48. Yang, H.; Ge, W.C.; Bi, J.H.; Wang, Z.H.; Tian, D.X.; Dong, Y.; Chen, H.J. The Neoproterozoic-Early Paleozoic evolution of the Jiamusi Block, NE China and its East Gondwana connection: Geochemical and zircon U-Pb-Hf isotopic constraints from the Mashan Complex. Gondwana Res. 2018, 54, 102-121. [CrossRef]

49. Liu, K.; Zhang, J.J.; Wilde, S.A.; Zhou, J.B.; Wang, M.; Ge, M.H.; Wang, J.M.; Ling, Y.Y. Initial subduction of the Paleo-Pacific Oceanic plate in NE China: Constraints from whole0rock geochemistry and zircon U-Pb and Lu-Hf isotopes of the Khanka Lake granitoids. Lithos 2017, 274-275, 254-270. [CrossRef]

50. Tang, J.; Xu, W.L.; Wang, F.; Ge, W.C. Subduction history of the Paleo-Pacific slab beneath Eurasian continent: Mesozoic-Paleogene magmatic records in Northeast Asia. Sci. China Earth Sci. 2018, 61, 527-559. [CrossRef]

51. Shirey, S.B.; Walker, R.J. Carius Tube Digestion for Low-Blank Rhenium-Osmium Analysis. Anal. Chem. 1995, 67, $2136-2141$. [CrossRef]

52. Du, A.D.; Zhao, D.M.; Wang, S.X.; Sun, D.Z.; Liu, D.Y. Precise Re-Os Dating for Molybdenite by ID-NTIMS with Carius Tube Sample Preparation. Rock Miner. Anal. 2001, 20, 247-252. (In Chinese)

53. Li, C.; Yang, X.; Zhao, H.; Zhou, L.M.; Du, A.D.; Li, X.W.; Qu, W.J. High Precise Isotopic Measurements of pg-ng Os by Negative Ion Thermal Ionization Mass Spectrometry. Rock Miner. Anal. 2015, 34, 392-398.

54. Zong, K.Q.; Klemd, R.; Yuan, Y.; He, Z.Y.; Guo, J.L.; Shi, X.L.; Liu, Y.S.; Hu, Z.C.; Zhang, Z.M. The assembly of Rodinia: The correlation of early Neoproterozoic (ca. $900 \mathrm{Ma}$ ) high-grade metamorphism and continental arc formation in the southern Beishan Orogen, southern Central Asian Orogenic Belt (CAOB). Precambrian Res. 2017, 290, 32-48. [CrossRef]

55. Hu, H.; Lentz, D.; Li, J.W.; McCarron, T.; Zhao, X.F.; Hall, D. Reequilibration processes in magnetite from iron skarn deposits. Econ. Geol. 2015, 110, 1-8. [CrossRef]

56. Liu, Y.S.; Hu, Z.C.; Gao, S.; Günther, D.; Xu, J.; Gao, C.G.; Chen, H.H. In situ analysis of major and trace elements of anhydrous minerals by LA-ICP-MS without applying an internal standard. Chem. Geol. 2008, 257, 34-43. [CrossRef]

57. Zhu, Z.Y.; Jiang, S.Y.; Ciobanu, C.L.; Yang, T.; Cook, N.J. Sulfur isotope fractionation in pyrite during laser ablation: Implications for laser ablation multiple collector inductively coupled plasma mass spectrometry mapping. Chem. Geol. 2017, 450, 223-234. [CrossRef]

58. Broughm, S.G.; Hanchar, J.M.; Tornos, F. Mineral chemistry of magnetite from magnetite-apatite mineralization and their host rocks: Examples from Kiruna, Sweden, and El Laco, Chile. Miner. Depos. 2017, 52, 1223-1244. [CrossRef]

59. Huang, X.W.; Beaudoin, G. Textures and chemical composition of magnetite from iron oxide-copper-gold (IOCG) and Kiruna-type iron oxide-apatite (IOA) deposits and their implications for ore genesis and magnetite classification schemes. Econ. Geol. 2019, 114, 953-979. [CrossRef]

60. Klemm, D.D.; Henckel, J.; Dehm, R.M.; Von Gruenewaldt, G. The geochemistry of titanomagnetite in magnetite layers and their host rocks of the eastern Bushveld Complex. Econ. Geol. 1985, 80, 1075-1088. [CrossRef]

61. Nadoll, P.; Koenig, A.E. LA-ICP-MS of magnetite: Methods and reference materials. J. Anal. At. Spectrom. 2011, $26,1872-1877$. [CrossRef] 
62. Dare, S.A.S.; Barnes, S.J.; Beaudoin, G. Variation in trace element content of magnetite crystallized from a fractionating sulfide liquid, Sudbury, Canada: Implications for provenance discrimination. Geochim. Cosmochim. Acta 2012, 88, 27-50. [CrossRef]

63. Dare, S.A.S.; Barnes, S.J.; Beaudoin, G.; Méric, J.; Boutroy, E.; Potvin-Doucet, C. Trace elements in magnetite as petrogenetic indicators. Miner. Depos. 2014, 49, 785-796. [CrossRef]

64. Nadoll, P.; Mauk, J.L.; Hayes, T.S.; Koenig, A.E.; Box, S.E. Geochemistry of magnetite from hydrothermal ore deposits and host rocks of the Mesoproterozoic Belt Supergroup, United States. Econ. Geol. 2012, 107, 1275-1292. [CrossRef]

65. Carew, M.J.; Mark, G.; Oliver, N.H.S.; Pearson, N. Trace element geochemistry of magnetite and pyrite in Fe oxide (+/-Cu-Au) mineralised systems: Insights into the geochemistry of ore-forming fluids. Geochim. Cosmochim. Acta 2006, 70, A83. [CrossRef]

66. Reguir, E.P.; Chakhmouradian, A.R.; Halden, N.M.; Yang, P.; Zaitsev, A.N. Early magmatic and reaction-induced trends in magnetite from the carbonatites of Kerimasi. Can. Mineral. 2008, 46, 879-900. [CrossRef]

67. Dupuis, C.; Beaudoin, G. Discriminant diagrams for iron oxide trace element fingerprinting of mineral deposit types. Miner. Depos. 2011, 46, 319-335. [CrossRef]

68. Galicki, M.; Marshall, D.; Staples, R.; Thorkelson, D.; Downie, C.; Gallagher, C.; Enkin, R.; Davis, W. Iron oxide \pm Cu \pm Au deposits in the Iron Range, Purcell Basin, southeastern British Columbia. Econ. Geol. 2012, 107, 1293-1301. [CrossRef]

69. Angerer, T.; Hagemann, S.G.; Danyushevsky, L. High-grade iron ore at Windarling, Yilgarn Craton: A product of syn-orogenic deformation, hypogene hydrothermal alteration and supergene modification in an Archean BIF-basalt lithostratigraphy. Mineral. Depos. 2013, 48, 697-728. [CrossRef]

70. Huang, X.; Qi, L.; Meng, Y. The element geochemistry of magnetite from Fe(-Cu) deposits in the Hami Region, Eastern Tianshan Orogenic Belt, NW China. Acta Geol. Sin. Engl. Ed. 2014, 88, 176-195. [CrossRef]

71. Boutroy, E.; Dare, S.A.S.; Beaudoin, G.; Barnes, S.J.; Lightfoot, P.C. Magnetite composition in Ni-Cu-PGE deposits worldwide and its application to mineral exploration. J. Geochem. Explor. 2014, 145, 64-81. [CrossRef]

72. Chen, W.T.; Zhou, M.F.; Gao, J.F.; Hu, R. Geochemistry of magnetite from Fe-Cu deposits in the Kangdian metallogenic province, SW China. Miner. Depos. 2015, 50, 795-809. [CrossRef]

73. Buddington, A.F.; Lindsley, D.H. Iron-titanium oxide minerals and synthetic equivalents. J. Petrol. 1964, 5, 310-357. [CrossRef]

74. Toplis, M.; Carroll, M. An experimental study of the influence of oxygen fugacity on Fe-Ti oxide stability, phase relations, and mineral-melt equilibria in ferro-basaltic systems. J. Petrol. 1995, 36, 1137-1170. [CrossRef]

75. Nadoll, P.; Angerer, T.; Mauk, J.L.; French, D.; Walshe, J. The chemistry of hydrothermal magnetite: A review. Ore Geol. Rev. 2014, 61, 1-32. [CrossRef]

76. Chen, W.T.; Zhou, M.F.; Li, X.; Gao, J.F.; Hou, K. In-situ LA-ICP-MS trace elemental analyses of magnetite: Cu-(Au, Fe) deposits in the Khetri copper belt in Rajasthan Province, NW India. Ore Geol. Rev. 2015, 65, 929-939. [CrossRef]

77. Van Baalen, M.R. Titanium mobility in metamorphic systems: A review. Chem. Geol. 1993, 100, 233-249. [CrossRef]

78. Liu, P.P.; Zhou, M.F.; Chen, W.T.; Gao, J.F.; Huang, X.W. In-situ LA-ICP-MS trace elemental analyses of magnetite: Fe-Ti-(V) oxide-bearing mafic-ultramafic layered intrusions of the Emeishan Large Igneous Province, SW China. Ore Geol. Rev. 2015, 65, 853-871. [CrossRef]

79. Huang, X.W.; Gao, J.F.; Qi, L.; Meng, Y.M.; Wang, Y.C.; Dai, Z.H. In-situ LA-ICP-MS trace elements analysis of magnetite: The Fenghuangshan Cu-Fe-Au deposit, Tongling, Eastern China. Ore Geol. Rev. 2016, 72, 746-759. [CrossRef]

80. Zhao, W.W.; Zhou, M.F. In-situ LA-ICP-MS trace elemental analyses of magnetite: The Mesozoic Tengtie skarn Fe deposit in the Nanling Range, South China. Ore Geol. Rev. 2015, 65, 872-883. [CrossRef]

81. Ding, M.P.; Tang, H.S.; Chen, Y.J.; Dong, L.H.; Li, J.H.; Qu, X.; Li, Q.G.; Sun, X.H.; Zhou, Z.J.; Shi, G.H. Genesis of the Erik iron ore deposit in the Taxkorgan area of the West Kunlun, Xinjiang: Constraints from ore deposit geology and in situ LA-ICP-MS analysis of magnetite. Earth Sci. 2018, 43, 3169-3185. (In Chinese)

82. Chung, D.; Zhou, M.F.; Gao, J.F.; Chen, W.T. In-situ LA-ICP-MS trace elemental analyses of magnetite: The late Palaeoproterozoic Sokoman Iron Formation in the Labrador Trough, Canada. Ore Geol. Rev. 2015, 65, 917-928. [CrossRef]

83. Balan, E.; Villiers, J.P.R.D.; Eeckhout, S.G.; Glatzel, P.; Toplis, M.J.; Fritsch, E.; Allard, T.; Galoisy, L.; Calas, G. The oxidation state of vanadium in titanomagnetite from layered basic intrusions. Am. Mineral. 2006, 91, 953-956. [CrossRef]

84. Bordage, A.; Balan, E.; Villiers, J.; Cromarty, R.; Juhin, A.; Carvallo, C.; Calas, G.; Raju, P.V.S.; Glatzel, P. V oxidation state in Fe-Ti oxides by high-energy resolution fluorescence-detected x-ray absorption spectroscopy. Phys. Chem. Miner. 2011, 38, 449-458. [CrossRef]

85. Sievwright, R.H.; Wilkinson, J.J.; O’Neill, H.S.C.; Berry, A.J. Thermodynamic controls on element partitioning between titanomagnetite and andesiti-dacitic silicate melts. Contrib. Mineral. Petrol. 2017, 172, 62. [CrossRef]

86. Toplis, M.J.; Corgne, A. An experimental study of element partitioning between magnetite, clinopyroxene and iron-bearing silicate liquids with particular emphasis on vanadium. Contrib. Mineral. Petrol. 2002, 144, 22-37. [CrossRef]

87. Hu, Z.C.; Zhang, W.; Liu, Y.S.; Gao, S.; Li, M.; Zong, K.Q.; Chen, H.H.; Hu, S.H. “Wave” Signal-Smoothing and Mercury-Removing Device for Laser Ablation Quadrupole and Multiple Collector ICPMS Analysis: Application to Lead Isotope Analysis. Anal. Chem. 2015, 87, 1152-1157. [CrossRef] [PubMed]

88. Ilton, E.S.; Eugster, H.P. A base metal exchange between magnetite and chloriderich hydrothermal fluid. Geochem. Cosmichim. Acta 1989, 53, 291-301. [CrossRef] 
89. Wen, G.; Li, J.W.; Hofstra, A.H.; Koenig, A.E.; Lowers, H.A.; Adams, D. Hydrothermal reequilibration of igneous magnetite in altered granitic plutons and its implications for magnetite classification schemes: Insights from the Handan-Xingtai iron district, North China Craton. Geochim. Cosmochim. Acta 2017, 213, 255-270. [CrossRef]

90. Salazar, E.; Barra, F.; Reich, M.; Simon, A.; Leisen, M.; Palma, G.; Romero, R.; Rojo, M. Trace element geochemistry of magnetite from the Cerro Negro Norte iron oxide-apatite deposit, northern Chile. Miner. Depos. 2020, 55, 409-428. [CrossRef]

91. Craig, J.R.; Vokes, F.M.; Solberg, T.N. Pyrite: Physical and chemical textures. Mineralium Deposita 1998, 34, 82-101. [CrossRef]

92. Zhou, T.F.; Zhang, L.J.; Yuan, F.; Fan, Y.; David, R.C. LA-ICP-MS in situ trace element analysis of pyrite from the Xinqiao Cu-Au-S deposit in Tongling Anhui and its constraints on the ore genesis. Earth Sci. Front. 2010, 17, 306-319. (In Chinese)

93. Yan, Y.T.; Li, S.R.; Jia, B.J.; Zhang, N.; Yan, L.N. Composition typomorphic characteristics and statistic analysis of pyrite in gold deposits of different genetic types. Earth Sci. Front. 2012, 19, 214-226. (In Chinese)

94. Zhang, J.; Deng, J.; Chen, H.Y.; Yang, L.Q.; Cooke, D.; Danyushevsky, L.; Gong, Q.J. LA-ICP-MS trace element analysis of pyrite from the Chang'an gold deposit, Sanjiang region, China: Implication for ore-forming process. Gondwana Res. 2014, 26, 557-575. [CrossRef]

95. Wang, L.; Zhu, Y. Multi-stage pyrite and hydrothermal mineral assemblage of the Hatu gold district (west Junggar, Xinjiang, NW China): Implications for metallogenic evolution. Ore Geol. Rev. 2015, 69, 243-267. [CrossRef]

96. Ohmoto, H.; Rye, R.O. Isotopes of sulfur and carbon. In Geochemistry of Hydrothermal Ore Deposits, 2nd ed.; Barnes, H.L., Ed.; John Wiley \& Sons: New York, NY, USA, 1979; pp. 509-567.

97. Wu, K.X.; Hu, R.Z.; Bi, X.W.; Peng, J.T.; Tang, Q.L. Ore Lead isotopes as a tracer for ore-forming material sources: A review. Geol.-Geochem. 2002, 30, 73-81. (In Chinese)

98. White, W.M. Geochemistry; John Wiley \& Sons Inc.: New York, NY, USA, 2013; pp. 406-409.

99. Loftus-Hills, G.; Solomon, M. Cobalt, nickel and selenium in sulphides as indicators of ore genesis. Miner. Depos. 1967, 2, 228-242. [CrossRef]

100. Bralia, A.; Sabatini, G.; Troja, F. A revaluation of the Co/Ni ratio in pyrite as geochemical tool in ore genesis problems. Miner. Depos. 1979, 14, 353-374. [CrossRef]

101. Brill, B. Trace-element contents and partitioning of elements in ore minerals from the CSA Cu-Pb-Zn deposit, Australia. Can. Mineral. 1989, 27, 263-274.

102. Duan, S.G.; Dong, M.H.; Zhang, Z.H.; Jiang, Z.S.; Li, F.M. A LA-ICP-MS analysis of element in magnetite from Dunde iron deposit in Western Tianshan Mountains, Xijiang: Constraints on genesis of the deposit. Miner. Depos. 2014, 33, 1325-1337. (In Chinese)

103. Gong, L.; Ma, G. The characteristic typomorphic composition of pyrite and its indicative meaning to metal deposits. Contrib. Geol. Miner. Resour. Res. 2011, 26, 162-166. (In Chinese)

104. Rye, R.O.; Ohmoto, H. Sulfur and Carbon Isotopes and Ore Genesis: A Review. Econ. Geol. 1974, 69, 826-842. [CrossRef]

105. Zheng, Y.F.; Chen, J.F. Geochemistry of Stable Isotopes; Science Press: Beijing, China, 2000; pp. 38-73. (In Chinese)

106. Stacey, J.S.; Hedlund, D.C. Lead-isotopic compositions of diverse igneous rocks and ore deposits from southwestern New Mexico and their implications for early Proterozoic crustal evolution in the western United States. Geol. Soc. Am. Bull. 1983, 94, 1558-1567. [CrossRef]

107. Zartman, R.E.; Doe, B.R. Plumbotectonics-the model. Tectonophysics 1981, 75, 135-162. [CrossRef]

108. Hao, Y.J.; Ren, Y.S.; Duan, M.X.; Zhao, X.; Yang, Q.; Tong, K.Y.; Li, C. Mineralization time and tectonic setting of the Zhengguang Au deposit in the Duobaoshan ore field, Heilongjiang Province, NE China. Arab. J. Geosci. 2016, 9, 655. [CrossRef]

109. Yang, Q.; Ren, Y.S.; Hao, Y.J.; Wang, B.; Sun, Z.M.; Li, J.M. Ore fluid, geochronology and tectonic setting of mesothermal gold metallogeny in southeastern Jilin Province, Northeast China: A case study of the Shajingou gold deposit. Ore Geol. Rev. 2019, 109, 229-252. [CrossRef]

110. Li, C.; Qu, W.J.; Wang, D.H.; Chen, Z.H.; Du, A.D. Advances in the study of the Re-Os isotopic system of organic-rich sample. Acta Petrol. Mineral. 2010, 29, 421-430. (In Chinese)

111. Maslennikov, V.V.; Ayupova, N.R.; Herrington, R.J.; Danyushevskiy, L.V.; Large, R.R. Ferruginous and manganiferous haloes around massive sulphide deposits of the Urals. Ore Geol. Rev. 2012, 47, 5-41. [CrossRef]

112. Knipping, J.L.; Bilenker, L.D.; Simon, A.C.; Reich, M.; Barra, F.; Deditius, A.P.; Wälle, M.; Heinrich, C.A.; Holtz, F.; Munizaga, R. Trace elements in magnetite from massive iron oxide-apatite deposits indicate a combined formation by igneous and magmatichydrothermal processes. Geochim. Cosmochim. Acta 2015, 171, 15-38. [CrossRef] 